\title{
Certain Caddo Sites on Stone Chimney Creek, Cherokee County, Texas
}

Mark Walters

Heritage Research Center, Stephen F. Austin State University

Timothy K. Perttula

Heritage Research Center, Stephen F. Austin State University

LeeAnna Schniebs

Follow this and additional works at: https://scholarworks.sfasu.edu/ita

Part of the American Material Culture Commons, Archaeological Anthropology Commons, Environmental Studies Commons, Other American Studies Commons, Other Arts and Humanities Commons, Other History of Art, Architecture, and Archaeology Commons, and the United States History Commons

Tell us how this article helped you.

This Article is brought to you for free and open access by the Center for Regional Heritage Research at SFA ScholarWorks. It has been accepted for inclusion in Index of Texas Archaeology: Open Access Gray Literature from the Lone Star State by an authorized editor of SFA ScholarWorks. For more information, please contact cdsscholarworks@sfasu.edu. 


\section{Certain Caddo Sites on Stone Chimney Creek, Cherokee County, Texas}

Creative Commons License

(c) (i) (8)

This work is licensed under a Creative Commons Attribution-NonCommercial 4.0 International License 


\title{
Certain Caddo Sites on Stone Chimney Creek, Cherokee County, Texas
}

\author{
Mark Walters and Timothy K. Perttula, with a contribution by LeeAnna Schniebs
}

\section{INTRODUCTION}

Limited archaeological investigations coupled with private landowner's surface collections on Stone Chimney Creek in northwestern Cherokee County, Texas has resulted in the recording of nine new Caddo sites, several of which appear to have been occupied after ca. A.D. 1650 in the Allen phase. The landowner had collected artifacts on his farm and contacted the Texas Historical Commission (THC) about getting information about them, who in turn contacted the author, a member of the Texas Archeological Stewardship Network. The landowner was interested in learning more about the native inhabitants who had once called this portion of Stone Chimney Creek home.

Stone Chimney Creek originates in northern Cherokee County and flows in a southerly direction before joining the Neches River under present day Lake Palestine (Figure 1a-b). The study area is some 4.8 $\mathrm{km}$ north of the confluence of Stone Chimney Creek and the Neches River. Stone Chimney Creek, in the study area, is deeply entrenched with a narrow floodplain and steep valley walls. Therefore, in the study area, there are no good alluvial settings for archaeological sites. Rather, archaeological sites are located on upland slopes or on top of upland landforms paralleling Stone Chimney Creek. Some of the site settings are unusual, being at the head of dry drainages and gullies, as they are in the adjoining Flat Creek basin (Perttula and Nelson 2007, 2009a, 2009b; Perttula et al. 2010) and long distances (in terms of easy access to water) from Stone Chimney Creek proper.

The soils in the study area are of the Nacogdoches series, which are the principal red soils in the Redlands section of East Texas. The iron and red pigments in these soils permeate everything: skin, clothing, the outside of houses, even artifacts. Depending on the degree of slope, soil layers and fertility vary across the study area; the steeper slopes are heavily eroded. Parent material is greensand marl or glauconitic sandy clay and clay (Mowery and Oakes 1958:26-27). Certain locations in the study area have been mined of soil for construction purposes. There is evidence of old farming activities, such as farming terraces, but currently large portions of the study area have been cleared and developed for pasture. This land clearing and mining provided good surface visibility at certain sites, resulting in some large surface collections from those areas. Shovel tests were conducted at six of the recorded sites and a $1 \mathrm{x} 1 \mathrm{~m}$ test unit was placed in a midden deposit at 41CE426. This article characterizes the work to date on these Stone Chimney Creek sites, focusing mainly on five sites with the largest surface collections. The article concludes with a discussion of the broader character and cultural affiliation of these sites with respect to the recently defined Upper Neches River cluster of Historic Caddo sites (Perttula 2007; Marceaux 2011).

\section{BACKGROUND}

In the Neches River basin, after A.D. 1400, Caddo settlements include sites of the Frankston phase and the later Allen phase. The Frankston phase (ca. A.D. 1400-1650) is thought to have developed into the Allen phase (ca. A.D. 1650-1800) (Story and Creel 1982:34). In addition to traditionally made and decorated Caddo ceramics, including the distinctive type Patton Engraved, Allen phase sites tend to have scant amounts of European trade goods, such as gunflints, gun parts, and glass beads. The Allen phase 


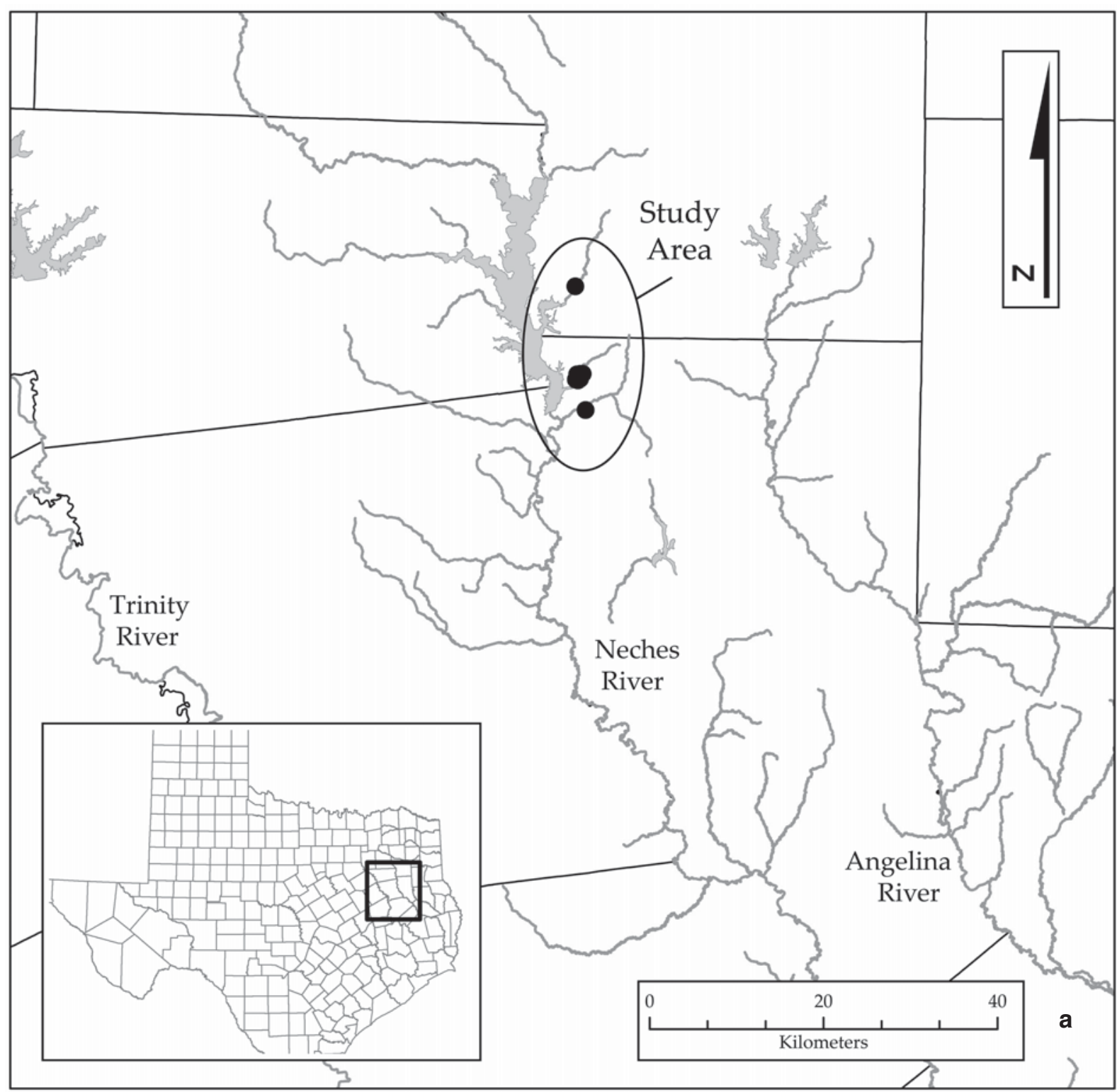

Figure 1. The study area: a, regional context, with sites on Saline Creek, Stone Chimney Creek, and Flat Creek in the upper Neches River basin in East Texas.

groups who occupied the Neches and Angelina river basins are thought to be direct ancestors of the Hasinai tribes who interacted with the Spanish missionaries and soldiers that occupied the area between ca. A.D. $1690-1731$.

This article focuses on the nine sites on Stone Chimney Creek in the Neches River drainage and previous work relating to the Frankston and Allen phases that has been done in the vicinity (see Figure 1a-b). The study group of nine sites occurs in a relatively small geographic area (less than $1 \mathrm{~km}$ in length, see Figure 1b). The percentages of brushed pottery, which ranges from more than $71 \%$ to $90+\%$, and evidence of Patton Engraved sherds at four of the sites, suggest that all of the Stone Chimney Creek sites were occupied in Historic Caddo Allen phase times. It is tempting to suggest that all of these sites were contemporaneous, forming an extended and dispersed village in the Stone Chimney Creek valley. What is not known is if these nine sites constitute an isolated community or are part of a larger Historic Caddo settlement. 


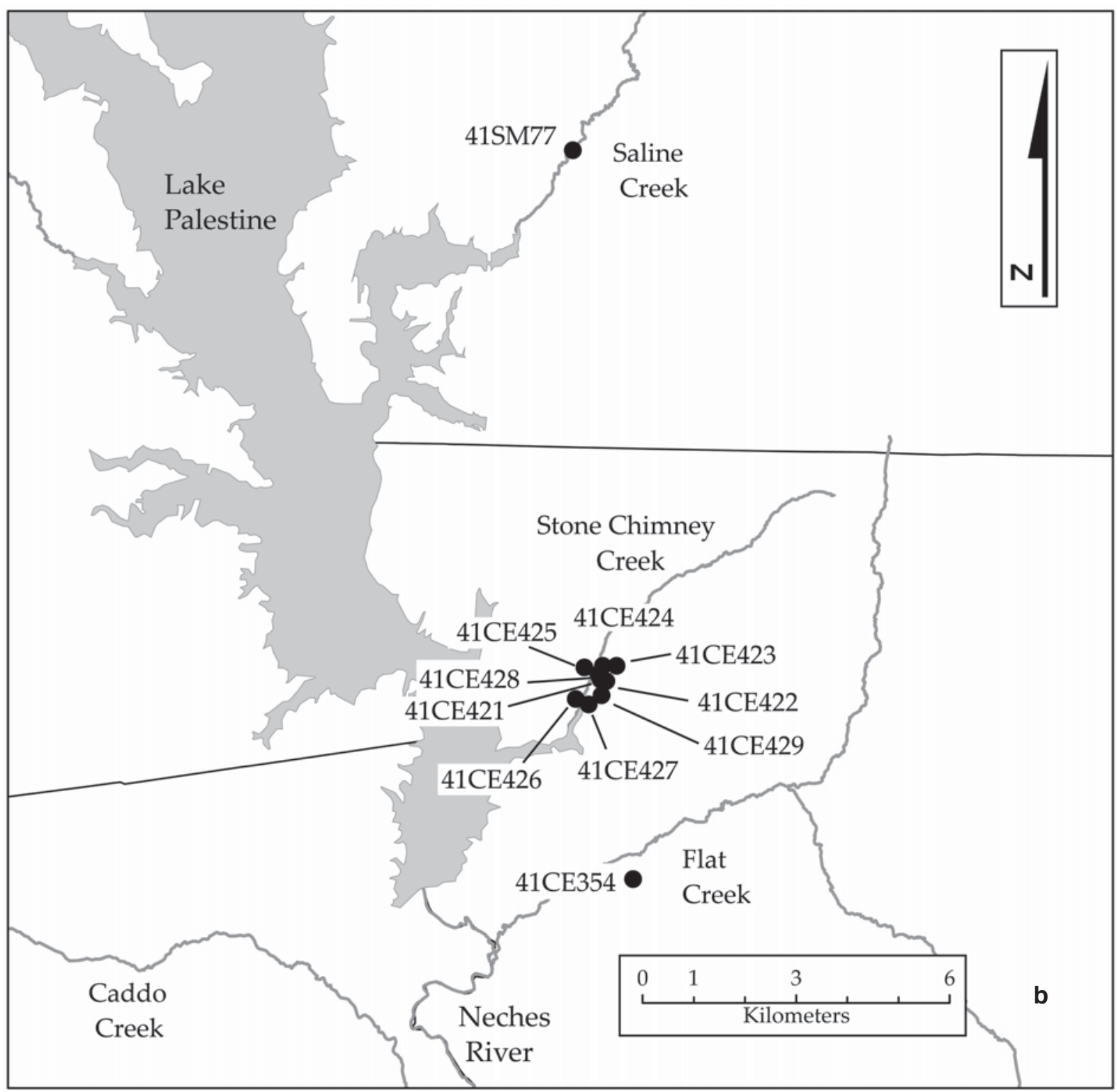

Figure 1. The study area: b, local context, with sites on Saline Creek, Stone Chimney Creek, and Flat Creek in the upper Neches River basin in East Texas.

Previous archaeological investigations in the area include salvage work done within or near Lake Palestine, where 10 sites were excavated before construction of the dam and lake. Several of these 10 sites had Frankston phase occupations, the William Sherman site had an example of Poynor/Patton Engraved (Anderson et al. 1974:Figure 76b), as well as assemblages with more than $50 \%$ brushed pottery. The Stone Chimney sites, with brushed percentages of $90 \%+$, would seem to fall later in time than the Lake Palestine sites.

An unrecorded site some $4 \mathrm{~km}$ north of the study area has a Patton Engraved rim sherd from a carinated bowl (Figure 2). The sherd has grog/hematite temper and is $6.1 \mathrm{~mm}$ thick. It is from a vessel that has been fired in a reduced atmosphere and cooled in the open air (see Teltser 1993:Figure 2). There is a horizontal row of pendant triangles above the carination point with white pigment in the lines.

The furthest north (some $10 \mathrm{~km}$ ) any known examples of Patton Engraved are found in this part of the Upper Neches River basin is a Patton/Poynor Engraved vessel from Burial 4 at the FIN S 20 


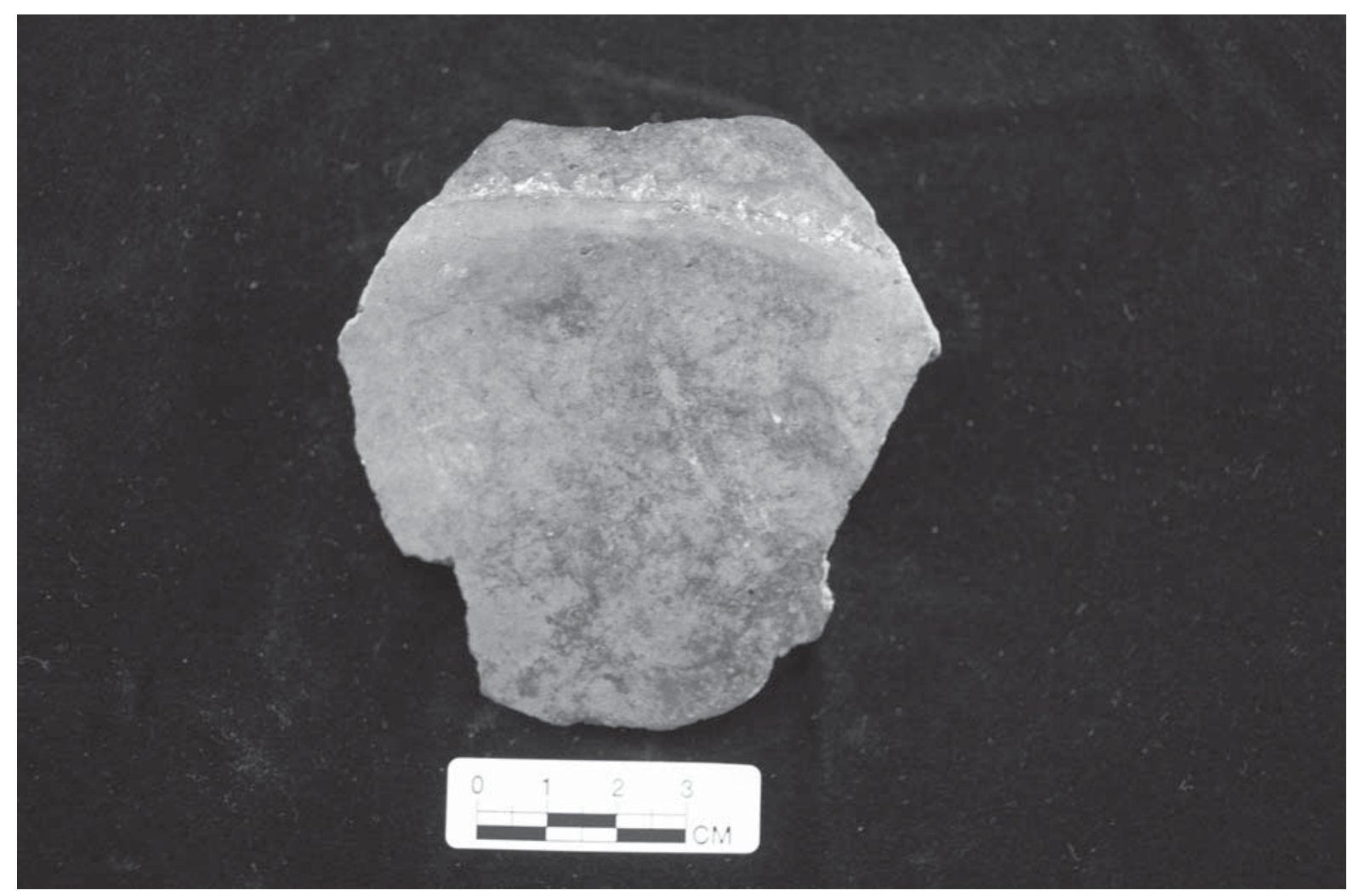

Figure 2. Patton Engraved carinated bowl sherd from an unrecorded site $4 \mathrm{~km}$ north of the study area.

(41SM77) site on Saline Creek in southern Smith County, Texas (Perttula 2006:Figure 217; see also Johnson 1961) The vessel decoration consists of hatched panel dividers forming negative ovals with two rows of excised triangles and white pigment in the lines. This vessel is part of the Buddy C. Jones collection at the Gregg County Historical Museum in Longview, Texas.

To the south of the Stone Chimney Creek sites on Flat Creek, test excavations at the Kah-hah-kowha site (41CE354) revealed an Allen phase (ca. A.D 1650-1800) occupation (Perttula and Nelson 2007). Ceramics recovered include Patton Engraved fine wares and $80+\%$ brushed wares. In addition, two gunflints and an iron fragment that may have been part of an iron kettle were found. (Perttula 2006:Figures 70-71). Based on the percentage of brushed sherds, several of the Stone Chimney Creek sites date later than the Kah-hah-ko-wha site. Other Historic Caddo sites recently recorded on Flat Creek include the Blue Branch, Pendulum, and Pine Snake sites (Perttula and Nelson 2009b; Perttula et al. 2010). The Pine Snake artifact assemblage includes pieces of obsidian from a northern New Mexico source.

\section{NINE STONE CHIMNEY CREEK SITES IN THE STUDY AREA}

\section{CE421}

41CE421 is located on a sandy slope some $0.19 \mathrm{~km}$ east of Stone Chimney Creek (see Figure 1b). A spring that feeds into Stone Chimney Creek is located on the south side of the site. An eroding field road coupled with recent land clearing, including leveling of old farming terraces, resulted in many exposures where a large surface collection of artifacts was gathered by the landowner (Table 1). Based on surface observation, the site covers $2500 \mathrm{~m}^{2}$ (0.6 acres) Shovel tests indicate the archaeological deposits are in 
Table 1. Artifacts recovered from $41 \mathrm{CE} 421$.

\begin{tabular}{lll}
\hline Artifact Category & N & Percent \\
\hline Caddo ceramic sherds & 2353 & 98.3 \\
Partial engraved bowl & 1 & $<0.1$ \\
Sandy paste sherds & 7 & 0.3 \\
Chipped stone tools & 2 & 0.1 \\
Lithic debris & 18 & 0.8 \\
Ceramic pipe sherds & 10 & 0.4 \\
Fired clay ball & 1 & $<0.1$ \\
Ground stone & 1 & $<0.1$ \\
\hline Totals & 2393 & 99.9 \\
\hline
\end{tabular}

a yellowish-brown sandy loam $\mathrm{A} / \mathrm{E}$ horizon, with numerous concretions of ironstone, that is $0-60 \mathrm{~cm}$ in thickness overlying a red clay B-horizon.

The vast majority of artifacts in the surface collection are Caddo ceramic sherds (98.3\%), followed by lithic debris from the manufacture of chipped stone tools, and pipe sherds. There are also a few sandy paste sherds-Goose Creek Plain, var. unspecified - chipped stone tools, portions of a reconstructed ceramic vessel, a fired clay ball, and a single ground stone tool (see Table 1).

The Caddo ceramic sherd assemblage is dominated by decorated utility ware rim and body sherds, as these account for $74.2 \%$ of all the sherds, and $96.7 \%$ of all the decorated sherds (Table 2). Plain rims are relatively abundant, indicating that the $41 \mathrm{CE} 421$ vessel sherds are from plain vessels as well as decorated fine wares and utility wares. Decorated fine ware sherds comprise only $2.5 \%$ of the assemblage.

The more than 1800 decorated sherds in the 41CE421 assemblage are dominated by sherds with brushing (Table 3). Brushed, brushed-tool punctated, and brushed-incised sherds account for $88.1 \%$ of the decorated sherds, followed by sherds with incised (4.1\%), engraved (3.3\%), and punctated $(2.1 \%)$ decorations. There are also sherds from vessels with pinched, neck banded, and appliqued decorations.

Table 2. The Caddo ceramic sherd assemblage from 41CE421.

\begin{tabular}{lll}
\hline Sherd Type & $\mathrm{N}$ & Percent \\
\hline Plain body & 495 & 21.0 \\
Plain rims & 17 & 0.7 \\
Plain base & 36 & 1.5 \\
$\quad 548$ & 23.3 \\
$\quad$ Subtotal, plain sherds & 59 & 2.5 \\
Decorated fine ware & 1746 & 74.2 \\
Decorated utility ware & 1805 & 76.7 \\
$\quad$ Subtotal, decorated sherds & 2353 & 100.0 \\
\hline Totals & &
\end{tabular}


Table 3. Decorated Caddo Sherds from 41CE421.

\begin{tabular}{lll}
\hline Decorative Method & $\mathrm{N}$ & Percent \\
\hline Fine Ware & & \\
Patton Engraved & 16 & 0.9 \\
Other engraved & 43 & 2.4 \\
$\quad$ Subtotal & 59 & 3.3 \\
Utility Ware & & \\
Brushed & 1562 & 86.5 \\
Brushed/tool punctuated & 25 & 1.4 \\
Brushed-incised & 4 & 0.2 \\
Incised & 74 & 4.1 \\
Punctated & 38 & 2.1 \\
Punctated-incised & 4 & 0.2 \\
Tool punctated/appliqued noded & 1 & 0.1 \\
Neck banded & 13 & 0.7 \\
Pinched & 20 & 1.1 \\
Appliqued Noded & 3 & 0.2 \\
Appliqued & 2 & 0.1 \\
$\quad$ Sub-total & 1746 & 96.7 \\
\hline Totals & 1805 & 100.0 \\
\hline
\end{tabular}

\section{Decorated Fine Wares}

\section{Patton Engraved}

Sixteen of the 59 fine ware sherds (27\%) are identified as being from Patton Engraved vessels. All of the Patton Engraved sherds have triangular tick marks rather than linear ticks in the following elements: single straight line with triangular ticks $(n=11)$, single curved line with triangular ticks $(n=1)$, multiple straight lines with triangular ticks $(n=3)$, and opposing lines with triangular ticks $(n=1)$. No pigment was detected in any of the engraved lines.

Other fine ware decorated sherds include those with an engraved cross-hatched filled triangle $(n=1)$, and the cross-hatched triangle measures $2.4 \times 1.3 \mathrm{~mm}$ and is from a bottle; multiple curved engraved lines $(n=6)$; single curved engraved line $(n=1)$; opposed engraved lines $(n=12$, Figure $3 a)$; engraved straight lines with hatched pendant triangles $(n=1)$; multiple straight engraved lines $(n=6)$; and parallel engraved lines filled with hatched marks $(n=1)$. Two fine ware rim sherds are identified as Poynor Engraved with opposed engraved lines forming negative circles (Figure 3c-d); one of the rims has possible rim peaks. One sherd unidentified as to type is an engraved rim with lip notching and a single horizontal line below the lip (Figure 3e). Average sherd thickness for the decorated fine wares is $6.3 \mathrm{~mm}$. 


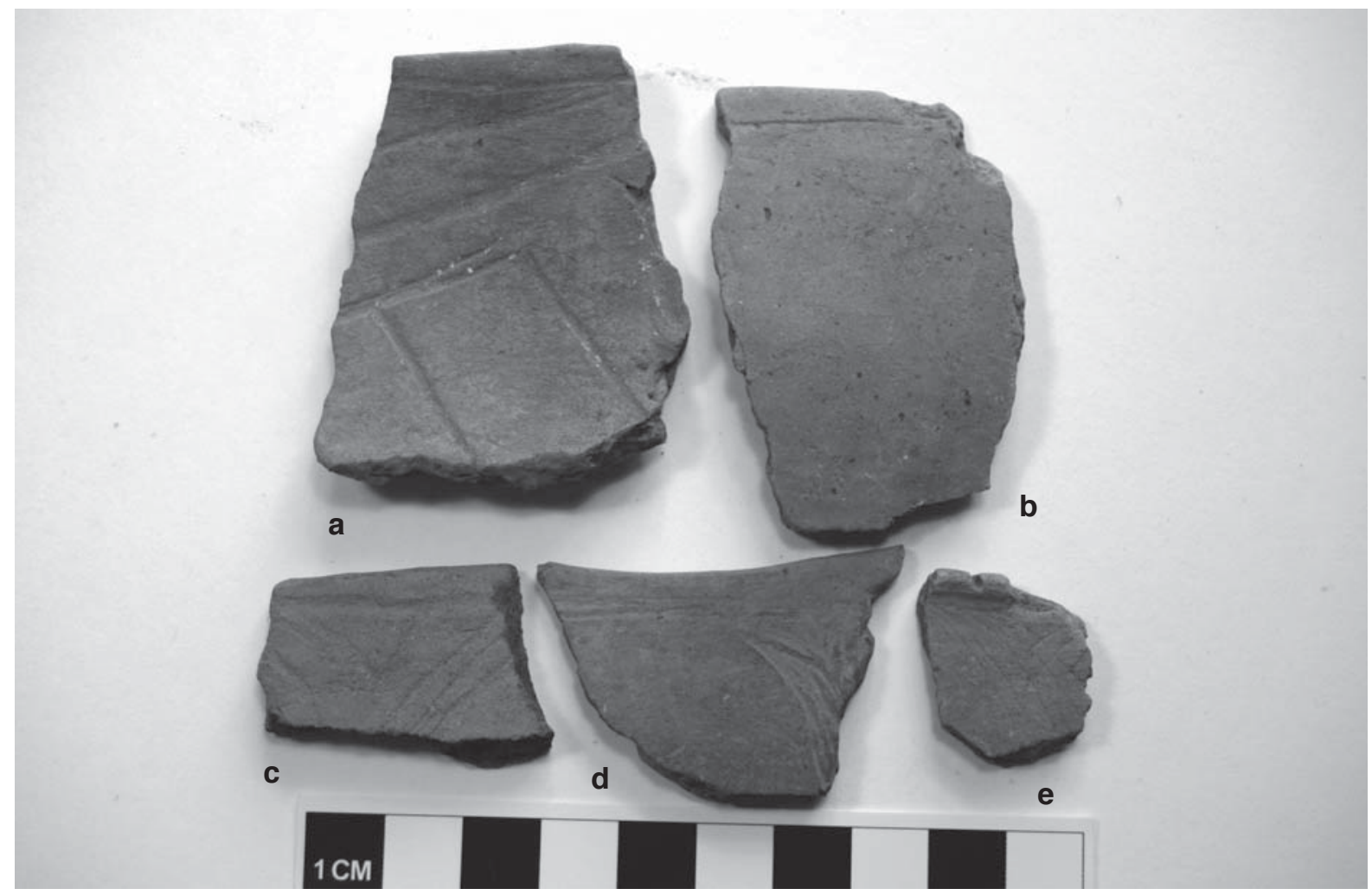

Figure 3. Engraved sherds from 41CE421: a, rim with opposing engraved lines; b, rim with horizontal line; c-d Poynor Engraved rims; e, engraved rim with lip notching.

\section{Partial Caddo bowl}

A partial ceramic carinated bowl was reconstructed from sherds collected from the surface at 41CE421 (Figure 4). It was identified as Poynor Engraved var. Blackburn. Nine rectangular panels were evenly spaced around the rim. The panels were divided by vertical engraved lines which formed triangles at the top and bottom of the vertical lines. The lines had a white pigment rubbed in them.

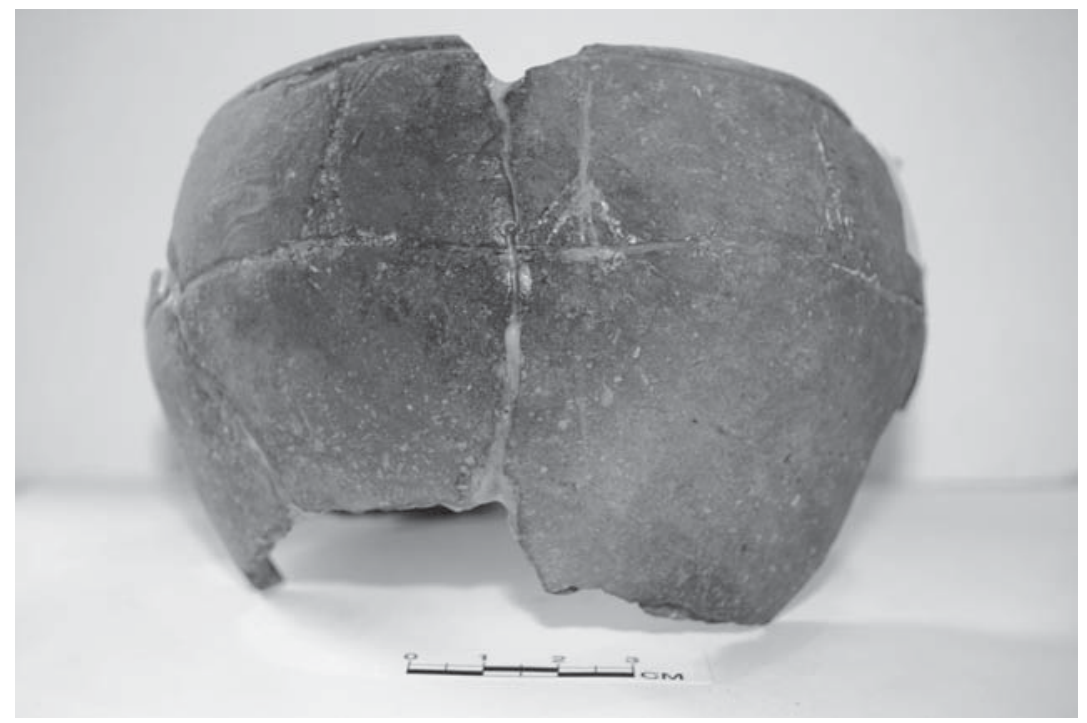

Figure 4. Poynor Engraved, var. Blackburn carinated bowl from 41CE421. 
NON-PLASTICS: grog

VESSEL FORM: carinated bowl

RIM AND LIP FORM: inverted rim with a rounded lip

CORE COLOR: B (fired and cooled in a reducing environment)

INTERIOR SURFACE COLOR: dark grayish-brown

EXTERIOR SURFACE COLOR: dark grayish-brown

WALL THICKNESS (RIM, BODY, AND BASE IN MM): rim, 7.0; body, 5.8; base, 9.8

INTERIOR SURFACE TREATMENT: smoothed

EXTERIOR SURFACE TREATMENT: smoothed

HEIGHT (IN CM): 7.9

ORIFICE DIAMETER (IN CM): 10.6

DIAMETER AT BOTTOM OF RIM OR NECK (IN CM): 12.0

BASE DIAMETER (IN CM): 5.0

DECORATION: engraved with rectangular panels

TYPE: Poynor Engraved, var. Blackburn

\section{Decorated Utility Wares}

There are 1746 decorated utility sherds from 41CE421. Almost $90 \%(\mathrm{n}=1562)$ are decorated by some form of brushing, including 1546 body sherds (Figure 5) and 16 rims. The brushed rims have horizontal brushing $(n=10)$, vertical brushing $(n=4)$, and diagonal brushing $(n=2)$.

The brushed sherds ( $\mathrm{n}=1562)$ have the following decorative elements:

$\begin{array}{lll}\text { Parallel brushed } & 1463 & 93.6 \% \\ \text { Opposed brushed } & 63 & 4.0 \% \\ \text { Overlapping brushed } & 18 & 1.2 \% \\ \text { Horizontal brushed } & 11 & 0.7 \% \\ \text { Vertical brushed } & 5 & 0.3 \% \\ \text { Diagonal brushed } & 2 & 0.1 \%\end{array}$

Parallel and opposed brushed elements are the most common, particularly the former. It is likely that the majority of the parallel brushed sherds are body sherds from vertically brushed jars.

The second most common utility ware decoration is incising. There are 68 incised body sherds (Figure 6a-d) and six incised rims: opposed incised $(n=3)$, straight incised line $(n=2)$, and cross-hatched incised $(n=1)$. Decorative elements present in the incised sherds $(n=74)$ are included in Table 4.

There are 38 punctated sherds in the 41CE421 sherd assemblage. Nine have tool punctates in rows, including five rims (see Figure 6f). There are 24 body sherds with random or freely placed tool punctates. Five sherds, including one rim, have fingernail punctates. 


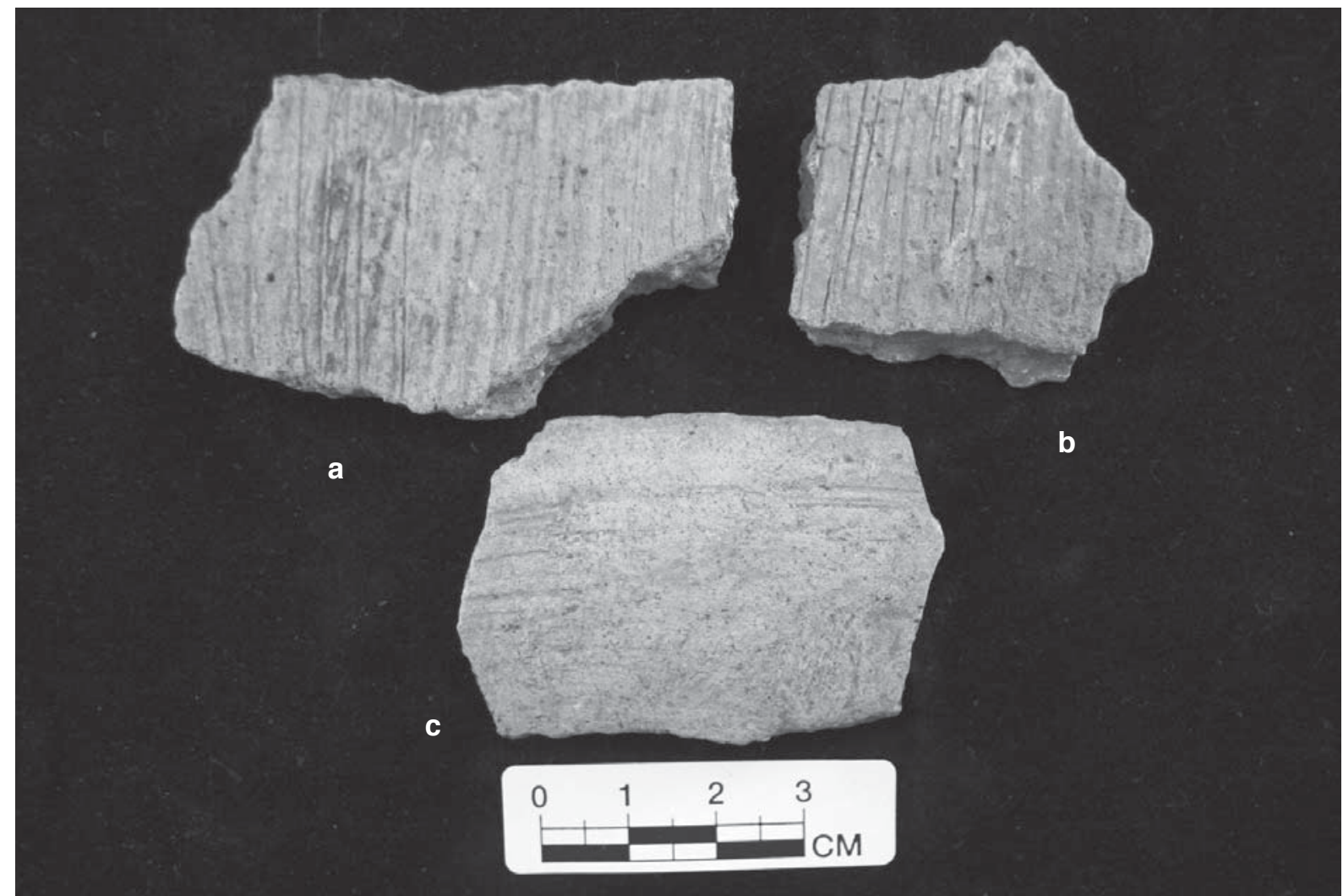

Figure 5. Parallel brushed body sherds from 41CE421: a-b, parallel brushed; c, horizontal brushed.

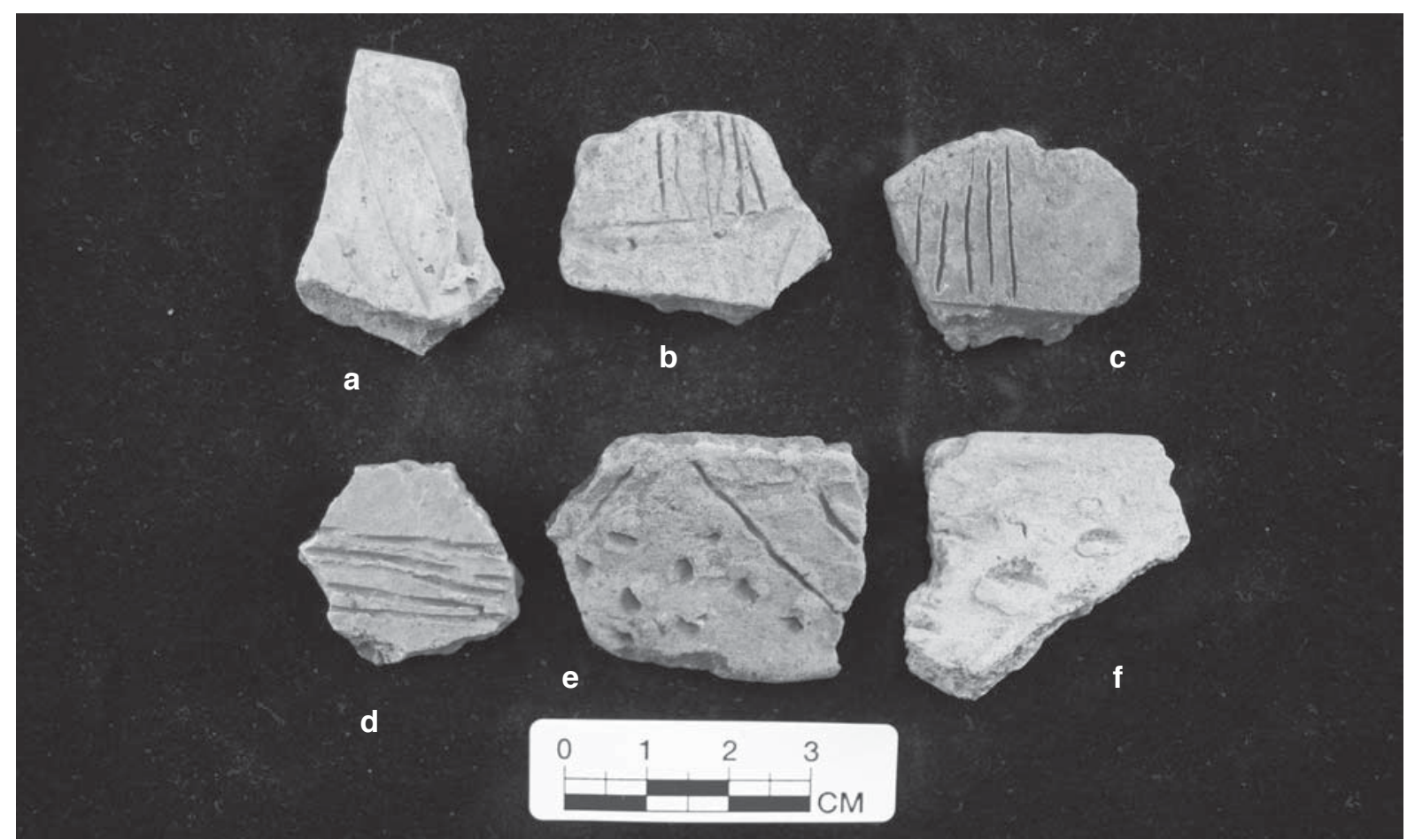

Figure 6. Incised, incised-punctated, and punctated sherds from 41CE421: a, diagonal incised; b-c opposing incised; d, parallel incised; e incised/punctated; f, punctated rim. 
Table 4. Incised decorative elements in the $41 \mathrm{CE} 421$ sherds.

\begin{tabular}{lll}
\hline Decorative element & No. & Percent \\
\hline Parallel incised & 37 & $50.0 \%$ \\
Straight incised line & 23 & $31.1 \%$ \\
Cross-hatched incised & 6 & $8.1 \%$ \\
Opposed incised & 6 & $8.1 \%$ \\
Curvilinear incised & 2 & $2.7 \%$ \\
\hline
\end{tabular}

The other decorated utility wares at 41CE421 include brushed-punctated (probably from Bullard Brushed jars), Killough Pinched, and LaRue Neck Banded sherds (Table 5). There are also a few Maydelle Incised sherds, including a rim with diagonal opposed incised lines and tool punctated-filled triangle elements (see Figure 6e), as well as appliqued and appliqued-punctated sherds.

Table 5. Other decorated utility ware sherds in the $41 \mathrm{CE} 421$ assemblage.

\begin{tabular}{ll}
\hline Decorative element & Number \\
\hline Brushed-punctated & 25 \\
Punctated-incised & 4 \\
Brushed-incised & 4 \\
Tool punctated/node & 1 \\
Nodes & 3 (including 1 rim) \\
Pinched (Killough Pinched) & 20 \\
Neck Banded & 13 (including 4 rims) \\
Appliqued fillet & 2 \\
\hline Totals & 72 \\
\hline
\end{tabular}

\section{Plain Caddo Sherds}

The plain ware sherds ( $\mathrm{n}=548)$ include 17 rims, 495 body sherds, and 36 bases. Plain rim and lip forms include: direct rim/rounded lip ( $n=9)$, direct rim/exterior folded lip $(n=3)$, inverted rim/exterior folded lip ( $\mathrm{n}=1)$, everted rim/exterior folded lip, rim peak $(\mathrm{n}=2)$, direct rim/rounded and exterior folded lip $(n=1)$, and everted rim/rounded lip $(n=1)$. These are primarily from bowls, but plain everted rim jars are also present in the assemblage.

The average thickness for the plain body sherds $(\mathrm{n}=495)$ is $7.9 \mathrm{~mm}$, indicating that the vessels were sturdy and probably large in size/volume. The average thickness of the flat bases is $13.0 \mathrm{~mm}$. One of the 36 bases was a ring base with a circular depression for a hollow pedestal (as with Killough Pinched vessels, see Suhm and Jelks 1962:Plate 46a-c) to fit in.

The plain/decorated sherd ratio (P/DR), excluding the 36 bases, is 0.28 . This $\mathrm{P} / \mathrm{DR}$ value places 41CE421 in Group I from comparative sherd assemblage and seriation data from Lake Palestine 
Middle-Historic Caddo sites and nearby (Allen phase) Caddo sites (Perttula 2007). We will return to a discussion of the ceramic seriation data from Upper Neches River Caddo sites later in this article.

The 41CE421 sherds are from vessels that are tempered primarily with grog, although hematite and bone were secondary temper inclusions (Table 6). There is very little difference between any of the wares with respect to temper selection, as grog is found in $66.7-73.8 \%$ of the four wares, grog-hematitetempered sherds account for $20-26.7 \%$ of the assemblage, and bone temper is found in $4.0-6.6 \%$ of the $41 \mathrm{CE} 421$ sherds. The low use of bone temper is consistent with other Historic Caddo assemblages in the upper Neches River basin.

Table 6. Temper Classes by Ceramic Ware from 41CE421.

\begin{tabular}{lllll}
\hline Wares & Grog & $\begin{array}{l}\text { Grog- } \\
\text { Hematite }\end{array}$ & Bone & Totals \\
\hline Fine ware & $69.3+$ & 26.7 & 4.0 & 100.0 \\
Utility ware & 66.7 & 26.7 & 6.6 & 100.0 \\
Brushed ware & 70.4 & 24.7 & 4.9 & 100.0 \\
Plain ware & 73.8 & 20.0 & 6.2 & 100.0 \\
\hline
\end{tabular}

+percentage

Several different ways of firing ceramic vessels were followed by the Caddo potters that lived at 41CE421. The most important and well-controlled methods were vessels fired in a low oxygen or reducing environment (61\%) (Table 7), particularly firing where the vessel was cooled in the open air, leaving a thin oxidized zone on one or both surfaces of the vessel core. More than one-third of the sherds (36\%) were from vessels that were fired and cooled in a high oxygen environment. Only $3 \%$ of the vessels were not well-fired, and these were from vessels that were incompletely oxidized during firing.

Table 7. Firing conditions of the Ceramic Sherds from 41CE421.

\begin{tabular}{ll}
\hline Firing Conditions* & Percentage \\
\hline A (oxidizing environment) & 36.0 \\
B (reducing environment) & 17.0 \\
C-E (incomplete oxidized) & 3.0 \\
F-H (reduced but cooled in the open air) & 44.0 \\
\hline Total & 100.0 \\
\hline
\end{tabular}

*Categories are based on Teltser (1993:Figure 2a-h).

\section{Clay Pipes}

There are 10 ceramic pipe sherds in the 41CE421 collection. These include five plain elbow pipe bowl fragments (Figure 7c). One pipe bowl had engraved hatched pendant triangles below a flat lip (Figure $7 b)$. Other pipe decorations include tiny circular punctates on a pipe stem $(n=2$, Figure $7 a)$, triangular 


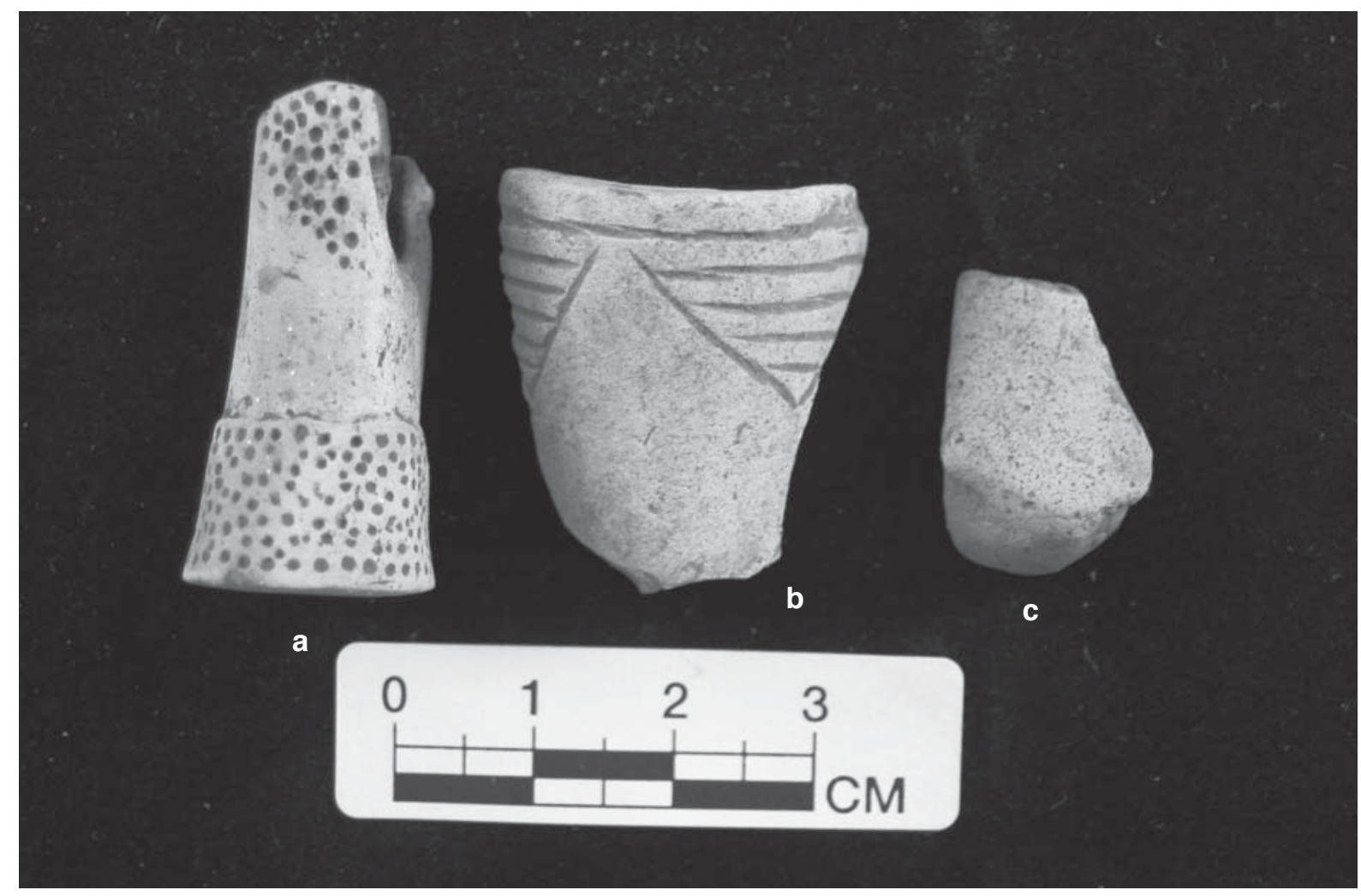

Figure 7. Ceramic pipe sherds from 41CE421: a, punctated pipe stem; b, engraved pipe bowl; c, plain elbow pipe sherd.

ticks $(n=1)$, and one sherd with a single engraved line $(n=1)$. These are typical Upper Neches River basin decorated elbow pipe styles (see Perttula 2011a:Figure 6-23, 2011b:Figures 9 and 16).

\section{Clay ball}

There is one fired clay ball (15.3 mm diameter) in the 41CE421 artifact collection with a smoothed surface. Similar fired clay balls were recovered from 41CE422.

\section{Sandy Paste Sherds}

Included in the artifacts from 41CE421 are seven sandy paste sherds, likely from Goose Creek Plain, var. unspecified vessels. These sandy paste sherds are from an earlier Woodland period occupation (dating from ca. 500 B.C. to A.D. 800) and are not included in the Caddo ceramic sherd analysis. Three of the sandy paste sherds are plain rims; two rims are inverted with rounded lips and one is direct with a rounded lip. There are four plain sandy paste body sherds.

\section{Lithic debris}

Lithic debris $(n=18)$ was not very abundant at 41CE421 (Table 8). All of it is from chert raw materials, including likely non-local gray chert $(56 \%)$ and locally available cherts ( $\tan$ and red chert, $44 \%)$. The low percentage of cortical flakes (5.6\%) suggests that the lithic debris is primarily the product of tool maintenance and resharpening activities of completed tools rather than the on-site manufacture of tools from cortex-covered pebbles, cobbles, or large flakes. 
Table 8. Lithic debris from 41CE421.

\begin{tabular}{lll}
\hline Material & Cortex & No. \\
\hline gray chert & non-cortical & 10 \\
tan chert & non-cortical & 4 \\
red chert & non-cortical & 3 \\
red chert & cortical & 1 \\
\hline Total & & 18 \\
\hline
\end{tabular}

\section{Chipped stone tools}

There were three chipped stone tools collected from 41CE421, including one expedient flake tool, one arrow point fragment, and one possible gunflint. The flake tool has bilateral edge retouch and use wear. It is made from a gray chert cortical flake. Its dimensions are: length, $31.5 \mathrm{~mm}$; width, $18.9 \mathrm{~mm}$; and thickness, $6.3 \mathrm{~mm}$. There is one unidentified arrow point medial section made from gray chert.

The possible gunflint is made from a gray chert (Figure 8). There is evidence of edge retouch on one end, while the opposite end had a snap fracture. The dimensions are: length, $25.1 \mathrm{~mm}$; width, $26.0 \mathrm{~mm}$; and thickness, $6.7 \mathrm{~mm}$.

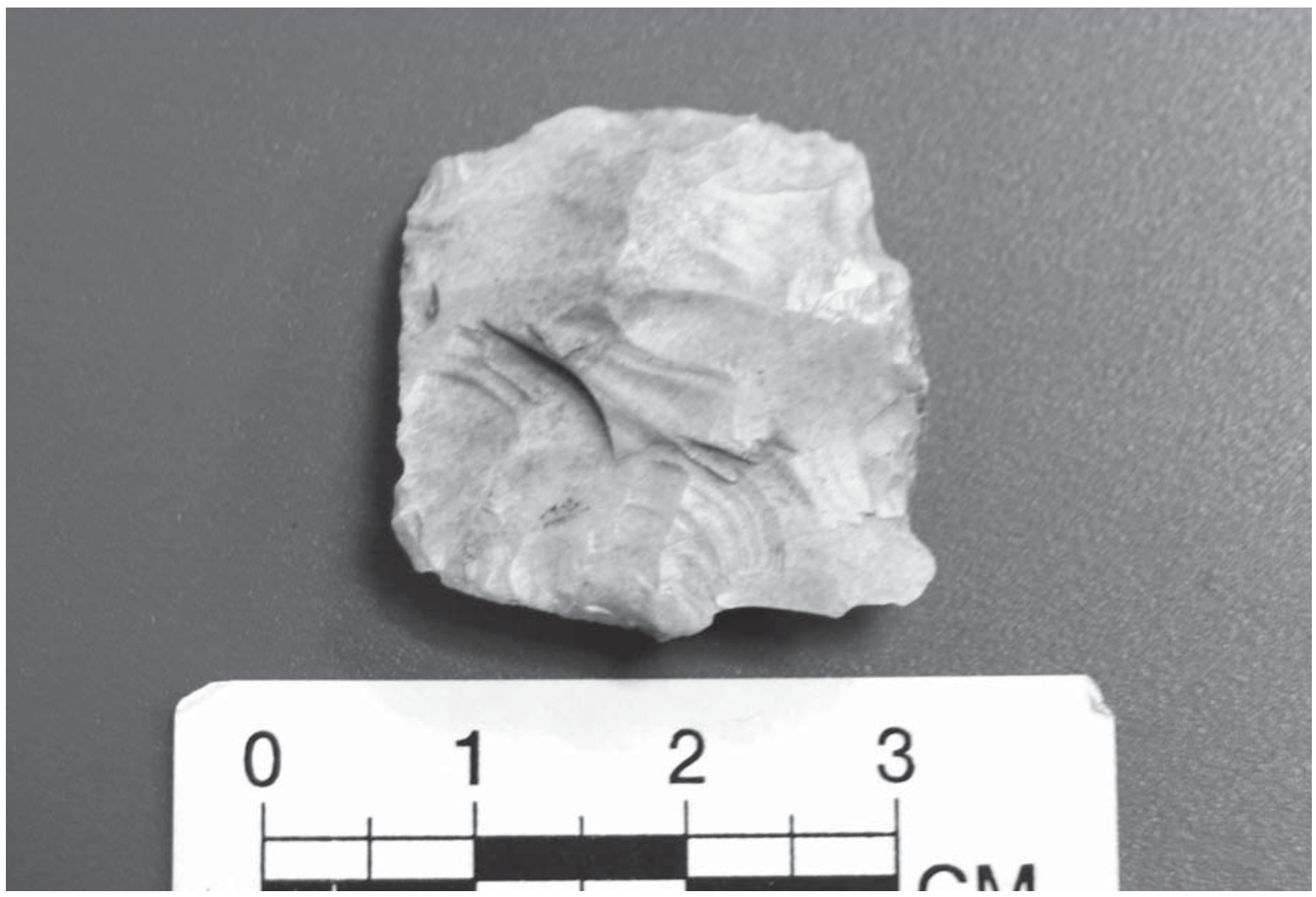

Figure 8. Possible gunflint from 41CE421. 


\section{Ground stone tool}

A ferruginous sandstone nutting stone was collected from the surface at 41CE421. One side is smoothed and slightly convex. The opposite side is smoothed, concave, and has a $3.0 \mathrm{~cm}$ circular depression or pit. Dimensions are: length, $13.0 \mathrm{~cm}$; width, $9.0 \mathrm{~cm}$; and thickness, $4.3 \mathrm{~cm}$.

\section{CE423}

41CE423 is located some $0.4 \mathrm{~km}$ east of Stone Chimney Creek (see Figure 1b) on an upland landform that has been subjected to extensive soil mining activities. This site is bordered on one side by a dry gully that ends at Stone Chimney Creek. This site, like 41CE429 (see below), is a long distance from present (and presumed past) water sources. Based on surface observations and limited shovel tests, the site covers some $3600 \mathrm{~m}^{2}$ ( 0.9 acres). Shovel tests in undisturbed areas indicate shallow reddish-brown soils of the Nacogdoches series, with numerous concretions of ironstone, overlying a red crumbly Bhorizon clay.

A total of 139 artifacts are in the collections from 41CE423. Over $91 \%$ of these artifacts are ceramic sherds (Table 9), 5\% are lithic debris, chipped stone tools and pipe sherds account for $1.4 \%$ each of the site sample, and the one ground stone tool represents $0.7 \%$ of the collection.

Table 9. Artifacts recovered from $41 \mathrm{CE} 423$.

\begin{tabular}{lll}
\hline Artifact Category & N & Percent \\
\hline Caddo ceramic sherds & 127 & 91.4 \\
Chipped stone tools & 2 & 1.4 \\
Lithic debris & 7 & 5.0 \\
Ceramic pipe sherds & 2 & 1.4 \\
Ground stone & 1 & 0.7 \\
\hline Totals & 139 & 99.9 \\
\hline
\end{tabular}

There were 127 ceramic sherds collected from 41CE423, the largest percentage of which are from utility wares (74.8\%) (Table 10). The average sherd thickness for the parallel brushed sherds was $8.0 \mathrm{~mm}$. The temper used in vessel manufacture was $63.3 \%$ grog, $30.0 \%$ grog/hematite-tempered, and $6.7 \%$ grog/ bone-tempered.

There were only two engraved fine ware sherds in the 41CE423 assemblage, both probably examples of Patton Engraved (Table 11). One had two rows of hatched pendant triangles (and could be from a Hume Engraved vessel); the other had a single straight engraved line with small triangles/ticks (Figure 9c-d).

The utility wares were dominated by parallel brushed body sherds (88.7\%). Brushed sherds number 89 or $91.8 \%$ of the decorated sherds in the ceramic assemblage (see Table 11). There were also five incised sherds: three with straight lines, one with diagonal lines, and one sherd with finely drawn concentric lines (see Figure 9a).

\section{Ceramic Pipes}

There were two ceramic pipe sherds in the 41CE423 artifact collection. One was a plain grog-hematite-tempered bowl rim fragment with a $4.0 \mathrm{~cm}$ orifice diameter. The second pipe fragment was a portion 
Table 10. The Caddo Ceramic Sherd Assemblage from 41CE423.

\begin{tabular}{lll}
\hline Sherd Type & N & Percent \\
\hline Plain body & 28 & 22.0 \\
Plain base & 2 & 1.6 \\
$\quad 30$ & 23.6 \\
Subtotal, Plain sherds & 2 & 1.6 \\
Decorated fine ware & 95 & 74.8 \\
Decorated utility ware & 97 & 76.4 \\
$\quad$ Subtotal, Decorated sherds & 127 & 100.0 \\
\hline Totals & &
\end{tabular}

Table 11. Decorated Sherds from 41CE423.

\begin{tabular}{lll}
\hline Decorative Method & $\mathrm{N}$ & Percent \\
\hline Fine Ware & 2 & \\
Engraved/Patton Engraved & 2 & 2.1 \\
$\quad$ Subtotal & & 2.1 \\
Utility Ware & 5 & \\
Incised & 86 & 5.2 \\
Parallel brushed & 2 & 88.7 \\
Overlapping brushed & 1 & 2.1 \\
Vertical brushed & 1 & 1.1 \\
Brushed/tool punctated & 95 & 1.1 \\
$\quad$ Subtotal & 97 & 98 \\
\hline Totals & & 100.1 \\
\hline
\end{tabular}

of the stem and bowl and had grog/bone temper. The stem had an outside diameter of $21.7 \mathrm{~mm}$ with a $14.3 \mathrm{~mm}$ opening. The stem had four horizontal incised lines around the rim or stem opening and the lower part of the bowl had a series of four horizontal incised lines (see Figure 9e).

\section{Chipped Stone Tools}

A Perdiz arrow point made from gray chert was found on the surface of 41CE423 (Table 12). It is $21.6 \mathrm{~mm}$ in length, $11.4 \mathrm{~mm}$ in width, and has a thickness of $2.4 \mathrm{~mm}$ (see Figure 9f). Other chipped stone tools include two expedient flake tools, as well as a gray chert dart point base with a rounded stem.

The lithic debris $(\mathrm{n}=8)$ was knapped from gray, brown/gray, and tan chert raw materials and a local gray quartzite (see Table 12). On-site tool manufacture occurred at 41CE423, based on the proportion of cortex in the lithic debris sample (37.5\%). 


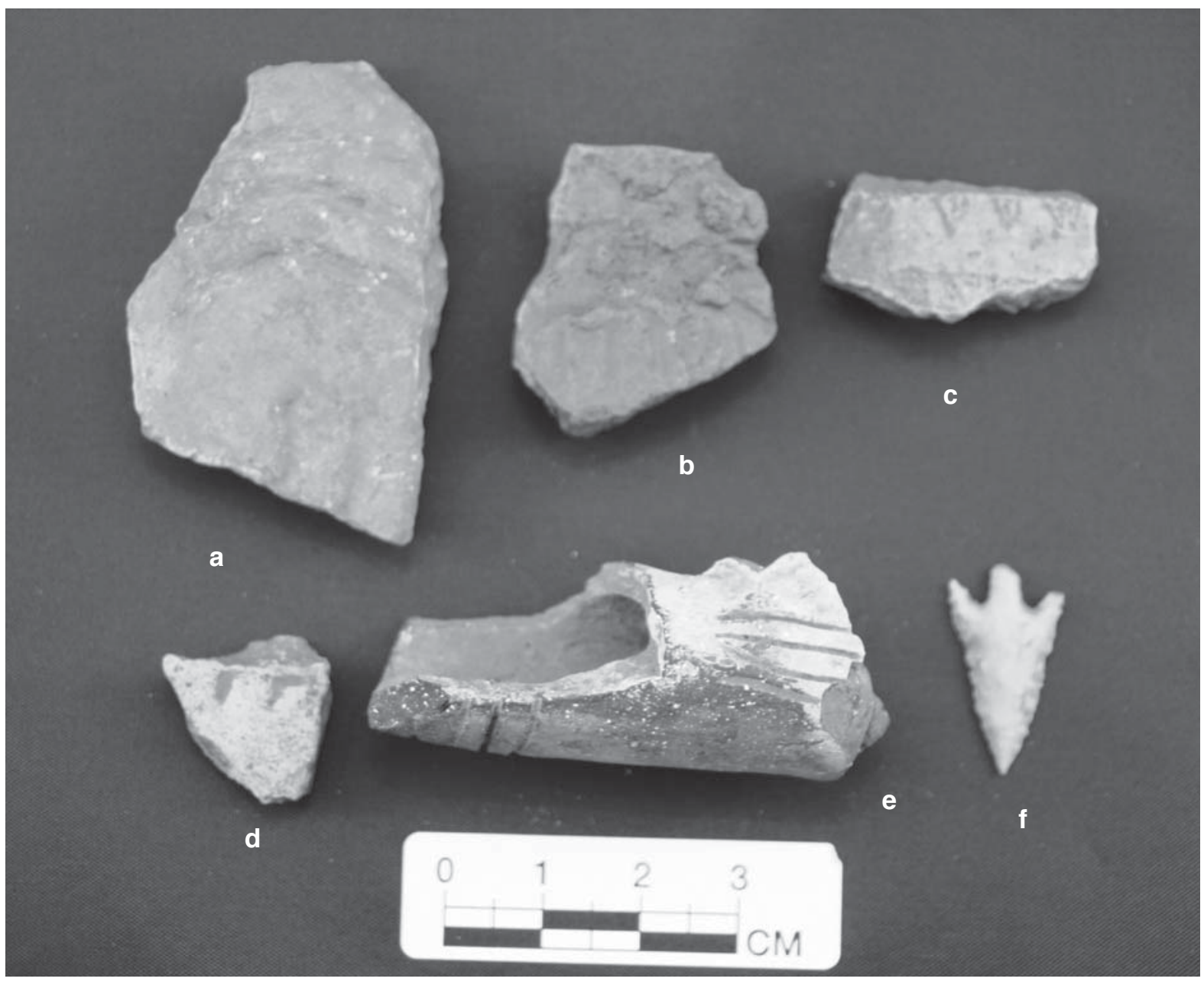

Figure 9. Selected artifacts from 41CE423: a, concentric incised body sherd; b, brushed-punctated sherd; c-d, Patton Engraved; e, incised pipe stem and lower bowl sherd; f, Perdiz arrow point.

Table 12. Lithic Debris and Tools from 41CE423.

\begin{tabular}{lllll}
\hline Raw Material & Cortical & Non-cortical & $\begin{array}{l}\text { Flake } \\
\text { tools }\end{array}$ & $\begin{array}{l}\text { Arrow } \\
\text { point }\end{array}$ \\
\hline Gray chert & 1 & 4 & 1 & 1 \\
Brown/gray chert & - & 1 & 1 & - \\
Tan chert & 1 & - & - & - \\
Gray quartzite & 1 & - & - & - \\
\hline Totals & 3 & 5 & 2 & 1 \\
\hline
\end{tabular}

A nutting stone or pitted stone was collected from the surface at 41CE423. It was made from ferruginous sandstone and had shallow $3 \mathrm{~cm}$ diameter holes on both sides. Dimensions of the tool are $9.5 \mathrm{~cm}$ in length, $5.0 \mathrm{~cm}$ in width, and $4.0 \mathrm{~cm}$ in thickness. 


\section{$41 \mathrm{CE} 422$}

41CE422 is located a short distance east of 41CE421 (see Figure 1b) and future work may determine that they are part of the same site. However, present information, based on surface observations, indicates that they are separated by some $50 \mathrm{~m}$ and a dry drainage or gully. The site core is located some $0.3 \mathrm{~km}$ from Stone Chimney Creek. Based on current observations, including limited shovel tests, the site covers some $4000 \mathrm{~m}^{2}$ (1.0 acres). The soils are a shallow reddish-brown sandy loam with numerous ironstone concretions overlying a dense red clay B-horizon.

A total of 44 prehistoric artifacts were recovered from 41CE422 (Table 13). More than 95\% of the artifacts were from surface collections. Two artifacts, a parallel brushed body sherd and a dart point midsection made from a white chert, were collected from $0-20 \mathrm{~cm}$ bs in a shovel test. There was one gray chert flake, non-cortical, found in the surface collection, along with five clay balls.

The sherds include 10 plain body sherds and one plain grog-hematite rim sherd (Table 14); the rim is direct with a rounded and exterior folded lip. The 10 plain body sherds average $7.4 \mathrm{~mm}$ in thickness. Fifty percent were tempered with grog and the other $50 \%$ had grog/hematite temper.

Table 13. Artifacts Recovered from 41CE422.

\begin{tabular}{lll}
\hline Artifact Category & $\mathrm{N}$ & Percent \\
\hline Caddo ceramic sherds & 37 & 84.1 \\
Clay balls & 5 & 11.4 \\
Chipped stone tools & 1 & 2.3 \\
Prehistoric lithic debris & 1 & 2.3 \\
\hline Totals & 44 & 100.1 \\
\hline
\end{tabular}

There are no fine ware sherds present in the small sherd collection from 41CE422 (see Table 14). Of the 26 utility sherds, $22(84.6 \%)$ are brushed (Table 15). About $86 \%$ of the brushed sherds have parallel brushing marks, two are overlapping brushed, and one rim has vertical brushing (Table 16). The brushed sherds are an average of $7.6 \mathrm{~mm}$ in thickness. About $45.5 \%$ of the brushed sherds are grog-tempered, $50 \%$ have grog/hematite temper, and $4.5 \%$ are tempered with grog and bone.

One body sherd in the utility ware assemblage from $41 \mathrm{CE} 422$ has random tool punctates. There are two incised body sherds with parallel lines. The third is a rim with horizontal incised lines; the rim is direct with a rounded lip.

\section{CE426}

41CE426 was first identified as a surface scatter of artifacts in a disturbed area where brush had been piled and burned. It is located some $40 \mathrm{~m}$ west of Stone Chimney Creek on a sandy upland landform that is currently in coastal Bermuda pasture (see Figure 1b). Shovel tests and limited surface observations indicate the site covers $3500 \mathrm{~m}^{2}$ (0.875 acres).

Ten positive shovel tests subsequently excavated at the site indicate that it has a reddish-brown sandy loam A-horizon that averaged $24.7 \mathrm{~cm}$ in depth overlying a red clay B-horizon. ST 6 was expanded into a $50 \times 50 \mathrm{~cm}$ unit to better sample concentrations of artifacts and midden soils identified in the shovel test. To obtain a larger sample of the contents of the midden deposit, a $1 \mathrm{x} 1 \mathrm{~m}$ test unit was placed adjacent to 
Table 14. The Caddo Ceramic Sherd Assemblage from 41CE422.

\begin{tabular}{lll}
\hline Sherd Type & N & Percent \\
\hline Plain rim & 1 & 2.7 \\
Plain body & 10 & 27.0 \\
Subtotal, Plain sherds & 11 & 29.7 \\
Decorated fine ware & - & 0.0 \\
Decorated utility ware & 26 & 70.3 \\
\multicolumn{1}{c}{ Subtotal, Decorated sherds } & 26 & 70.3 \\
\hline Totals & 37 & 100.0 \\
\hline
\end{tabular}

Table 15. Utility Wares from 41CE422.

\begin{tabular}{lll}
\hline Utility Wares & $\mathrm{N}$ & Percent \\
\hline Brushed & 22 & 84.6 \\
Incised & 3 & 11.5 \\
Punctated & 1 & 3.8 \\
\hline Totals & 26 & 99.9 \\
\hline
\end{tabular}

Table 16. Brushed Vessel Sherd Decorative Elements from 41CE422.

\begin{tabular}{ll}
\hline Decorative Class and Element & No. \\
\hline Parallel brushed & 19 \\
Overlapping brushed & 2 \\
Vertical brushed & 1 \\
\hline Totals & 22 \\
\hline
\end{tabular}

ST 6. A soil profile of the west wall of Unit 1 indicates a very dark brown (7.5YR 2.5/3) midden soil that extends to sterile red (2.5YR 2.5/4) clay at $22 \mathrm{~cm}$ bs.

A total of 210 artifacts have been recovered from investigations at 41CE426. Most of them are Caddo ceramic sherds (Table 17), but the artifacts also include chipped stone tools and lithic debris, ground stone tools, and a ceramic pipe sherd.

\section{Ceramic Vessel Sherds}

The average thickness of the $41 \mathrm{CE} 426$ sherds is $7.7 \mathrm{~mm}$. Approximately $58 \%$ of the sherds are grogtempered, $41 \%$ are grog- and hematite-tempered, while only $1 \%$ have bone temper. The plain/decorated sherd ratio (P/DR) for $41 \mathrm{CE} 426$ is 0.23 . 
Table 17. Artifacts Recovered from 41CE426.

\begin{tabular}{lll}
\hline Artifact Category & N & Percent \\
\hline Caddo ceramic sherds & 198 & 94.3 \\
Chipped stone tools & 1 & 0.5 \\
Prehistoric lithic debris & 7 & 3.3 \\
Ground stone & 3 & 1.4 \\
Ceramic pipe sherd & 1 & 0.5 \\
\hline Totals & 210 & 100 \\
\hline
\end{tabular}

\section{Fine Wares}

There are five decorated fine ware sherds (3.1\% of the decorated sherds, and $2.5 \%$ of all the sherds, Table 18). Three are from Patton Engraved vessels, two rims, and one body sherd. The first Patton Engraved rim (ST 5, 0-20 cm bs) is direct with a rounded lip. The grog-tempered rim is $8.5 \mathrm{~mm}$ thick and it has been fired in a reduced atmosphere. It is decorated with large excised pendant triangles from a single horizontal engraved line below the lip (Figure 10b). The second Patton Engraved rim (Unit 1, 10$20 \mathrm{~cm}$ bs) also has excised pendant triangles from a single horizontal engraved line and has grog-hematite temper. The rim is direct, with a rounded lip. The rim is $7.4 \mathrm{~mm}$ thick and is from a vessel that has been fired in a reduced atmosphere (Figure 10c).

The third Patton Engraved sherd (Unit 1, 10-20 cm bs) is a $4.8 \mathrm{~mm}$ thick body sherd from a grogtempered vessel. The sherd has been fired and cooled in a reduced atmosphere. The decoration on the sherd consists of a single straight engraved line with tick marks.

The other two engraved sherds are from King Engraved vessels, a new Historic Caddo ceramic type (Marceaux 2011; Middlebrook 2008; Perttula, Bush et al. 2010; Perttula et al. 2011). These two engraved cross-hatched sherds compare favorably with the type King Engraved as identified at the J.T. King site (Middlebrook 2008:4), but the small sherd sizes do not indicate if they are in panels or zones. The first King Engraved rim (ST 7, 0-20 cm bs) is direct with a rounded lip (Figure 11a). Its orifice diameter is $24.0 \mathrm{~cm}$. The rim is $6.3 \mathrm{~mm}$ thick and it has grog-hematite temper. It has engraved cross-hatching below the lip. The second King Engraved sherd is a body sherd (ST 7, 0-20 cm bs) with cross-hatching (Figure 11b). The sherd is grog-tempered, and $6.5 \mathrm{~mm}$ thick. It is from a vessel that had been fired in an oxidizing environment.

\section{Utility Wares}

Brushed sherds account for $95 \%$ of the utility wares from 41CE426. The vast majority of these sherds have parallel brushing marks, most from the body of brushed jars (Table 19).

There are also three brushed-punctated sherds, including two brushed-punctated rims with rows of tool punctates pushed through horizontal brushing (Bullard Brushed) and one brushed-punctate body sherd with rows of tool punctates pushed through parallel brushing marks (Table 20). The other utility ware sherds have brushed-appliqued $(n=1)$, incised $(n=2)$, and too punctated $(n=2)$ decorative elements.

The predominant method Caddo potters used in firing the vessels that were used at 41CE426 was to fire them in a reducing or low oxygen environment, but then to cool them in the open air (oxidizing environment). Almost $54 \%$ of the sherds from the site were fired in this way (Table 21). Another $13.2 \%$ were fired and cooled in a reducing environment. Almost one-third of the sherds are from vessels that 


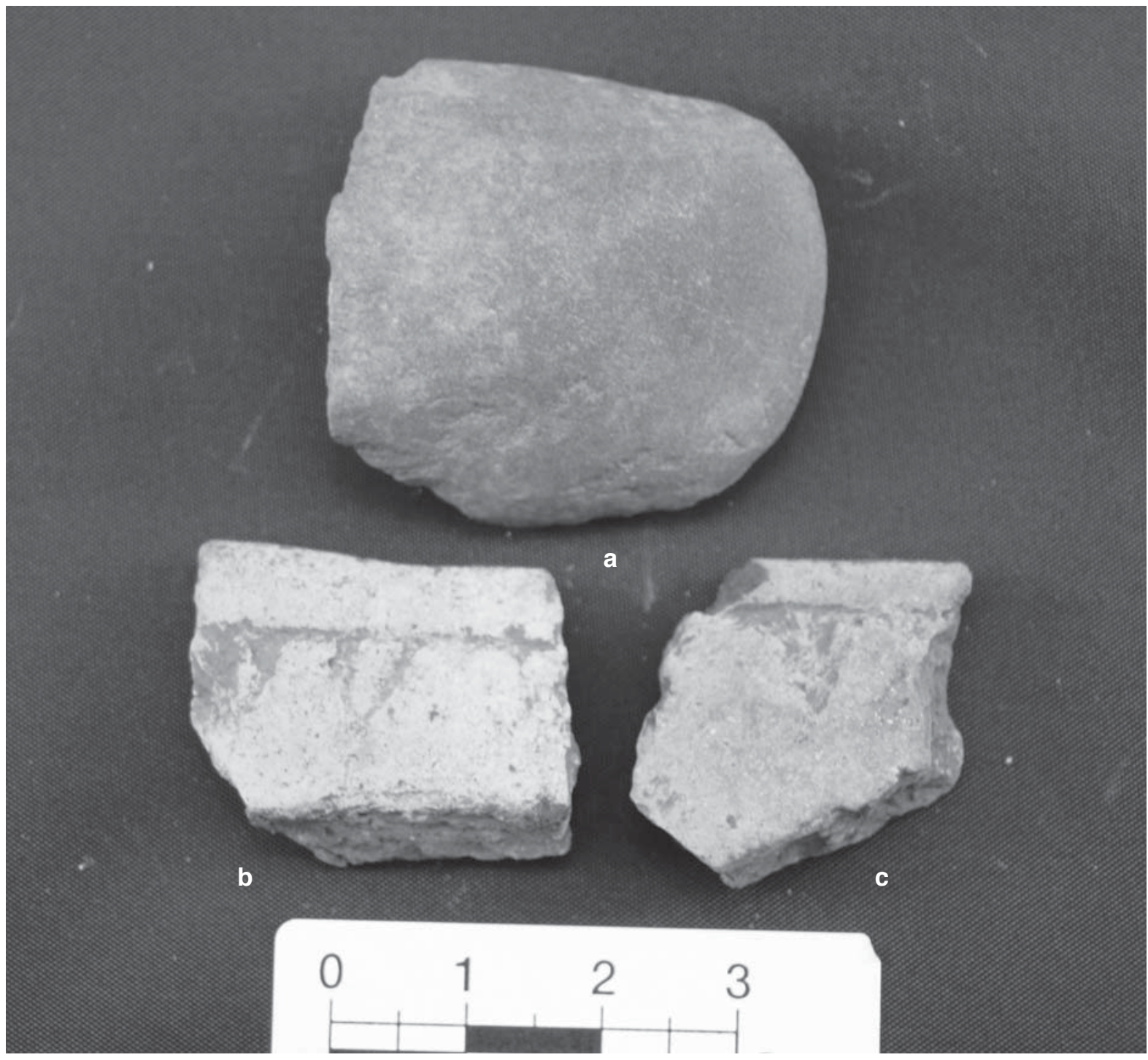

Figure 10. Selected artifacts from 41CE426: a, celt fragment; b-c, Patton Engraved rim sherds.

Table 18. The Caddo Ceramic Sherd Assemblage from 41CE426.

\begin{tabular}{lll}
\hline Sherd Type & No. & Percent \\
\hline Plain rim & 2 & 0.1 \\
Plain body & 35 & 17.7 \\
Plain base & 1 & 0.5 \\
$\quad$ Subtotal, Plain sherds & 38 & 19.2 \\
Decorated fine ware & 5 & 2.5 \\
Decorated utility ware & 155 & 78.3 \\
\multicolumn{1}{c}{ Subtotal, Decorated sherds } & 160 & 80.8 \\
\hline Totals & 198 & 100.0 \\
\hline
\end{tabular}




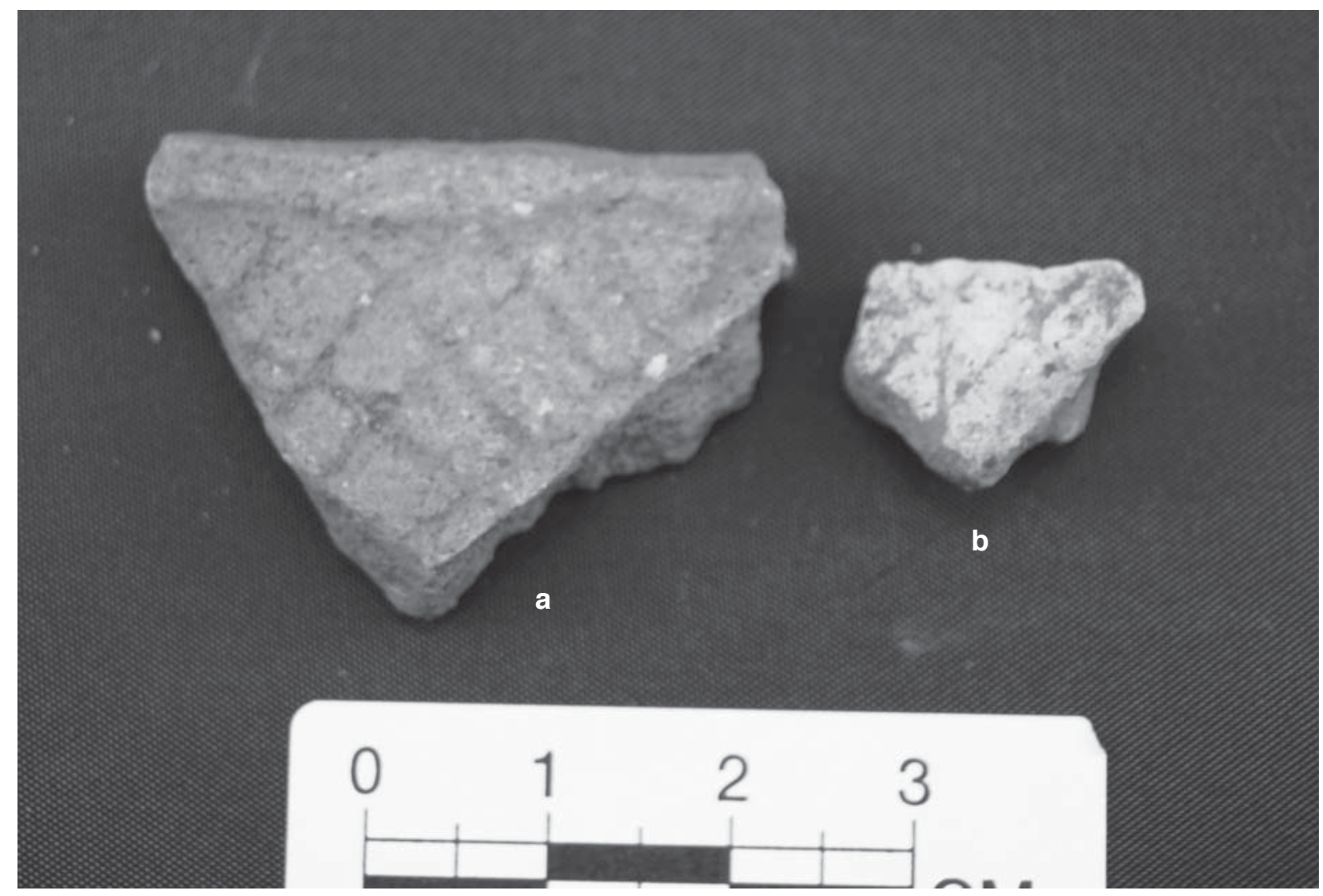

Figure 11. King Engraved sherds from 41CE426.

Table 19. Decorative Elements in the Brushed Vessel Sherds from 41CE426.

\begin{tabular}{ll}
\hline Decorative element & N \\
\hline Parallel brushed & 136 \\
Overlapping brushed & 7 \\
Vertical brushed & 2 \\
Horizontal brushed & 2 \\
\hline Totals & 147 \\
\hline
\end{tabular}

Table 20. Utility wares from $41 \mathrm{CE} 426$ other than those solely with Brushed elements.

\begin{tabular}{ll}
\hline Utility Wares & No. \\
\hline Brushed-punctated & 3 \\
Brushed-appliqued fillet & 1 \\
Incised & 2 \\
Tool punctated & 2 \\
\hline Totals & 8 \\
\hline
\end{tabular}


were fired and cooled in an oxidizing environment, leaving vessels with light red and yellow interior and exterior vessel surfaces as well as the vessel core.

\section{Ceramic Pipe Sherds}

Table 21. Firing Conditions of the Ceramic Sherds from 41CE426.

\begin{tabular}{ll}
\hline Firing conditions* & Percent \\
\hline A (oxidizing environment) & 31.1 \\
B (reducing environment) & 13.2 \\
E (incompletely oxidized) & 1.9 \\
F-H (reducing environment, cooled in the open air) & 53.8 \\
\hline Totals & 100.0 \\
\hline
\end{tabular}

*Categories are based on Teltser (1993:Figure 2)

One plain ceramic elbow pipe bowl sherd was recovered from Unit 1, 10-20 $\mathrm{cm}$ bs at $41 \mathrm{CE} 426$. The rim is everted and the lip rounded. It is grog-tempered, $3.4 \mathrm{~mm}$ thick, and has been fired in an oxidizing atmosphere.

\section{Ground Stone Tools}

A gray sandstone celt fragment was recovered from the surface (see Figure 10a). The bit end is polished. The second celt/pecking stone was recovered from ST 8, 0-19 cm bs. It is made from graywacke sandstone from an Ouachita Mountains raw material source area and has a smoothed surface. The poll end shows signs of battering. The bit end has been broken and reworked to create a blunt surface, perhaps used as a grinding or pecking tool (Figure 12).

The third ground stone tool is a ferruginous sandstone nutting stone. One surface has a $32.1 \mathrm{~mm}$ diameter circular depression. The opposite side has faint parallel grooves, suggesting it may also have been used as an abrader. Dimensions are: $77.0 \mathrm{~mm}$ in length, $72.0 \mathrm{~mm}$ in width, and $30.4 \mathrm{~mm}$ in thickness.

Only seven pieces of lithic debris are in the 41CE426 artifact assemblage (Table 22). This includes two cortical flakes of a local tan chert, which were from a pebble reduced on site, and five non-cortical flakes from a non-local gray chert and a local red hematite; the latter was likely produced in the shaping or refurbishing of a hematite ground stone tool.

\section{Flake Tool}

The one flake tool, from Unit 1, 0-10 cm bs, is made from a light gray chert and has edge retouch on one side. Dimensions of the tool are: $33.2 \mathrm{~mm}$ in length, $15.8 \mathrm{~mm}$ in width, and $3.5 \mathrm{~mm}$ in thickness. 


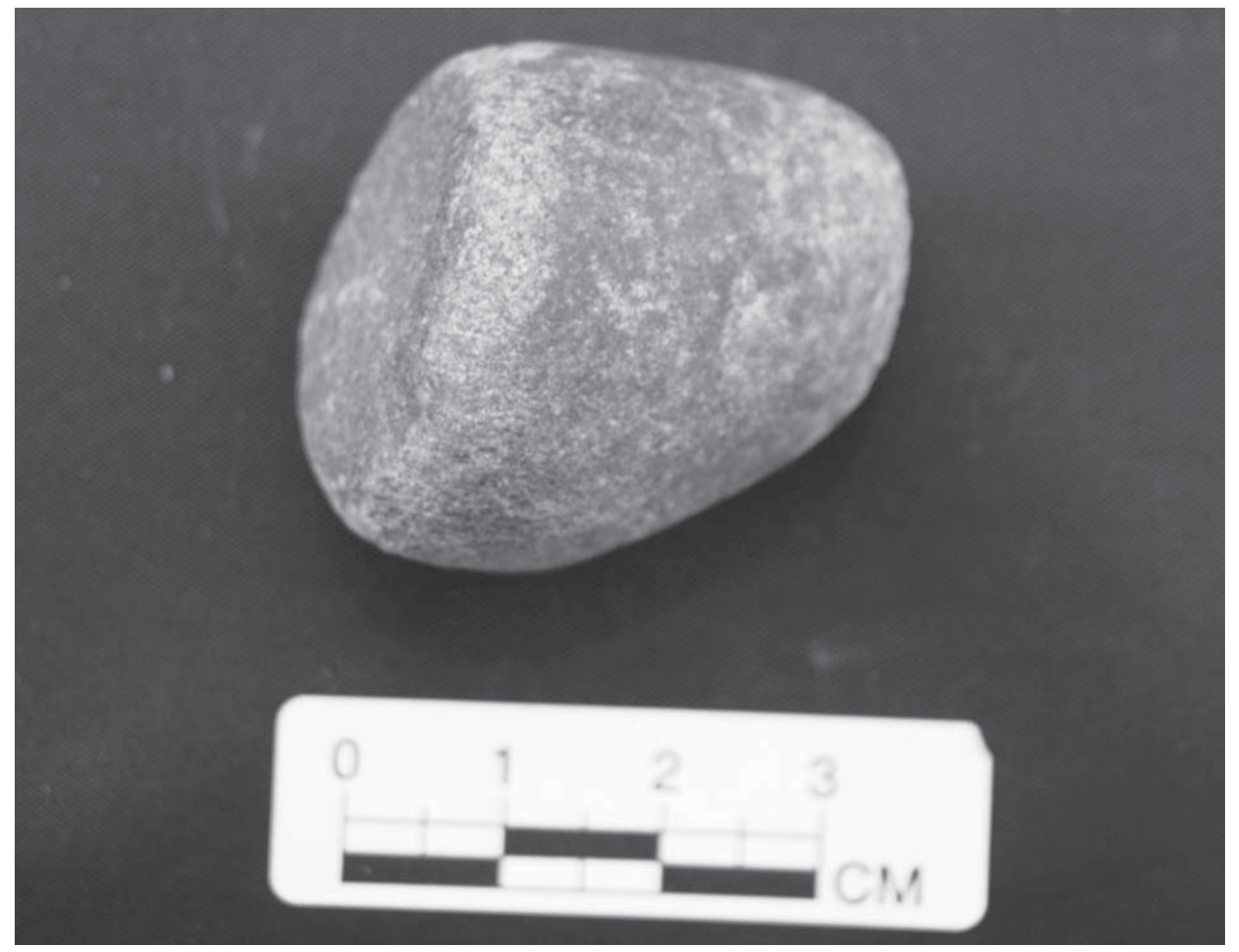

Figure 12. Celt or pecking stone.

Table 22. Lithic Debris from 41CE426.

\begin{tabular}{lll}
\hline Raw Material & Cortical & Non-cortical \\
\hline Tan chert & 2 & - \\
Gray chert & - & 3 \\
Light gray chert & - & 1 \\
Red hematite & - & 1 \\
\hline Totals & 2 & 5 \\
\hline
\end{tabular}




\title{
ANALYSIS OF FAUNAL REMAINS FROM 41CE426: A LATE 17TH CENTURY CADDO HABITATION SITE IN CHEROKEE COUNTY, TEXAS
}

\author{
LeeAnna Schniebs
}

Recent archaeological investigations at 41CE426 yielded 304 animal bone fragments (see Appendix 1). They were recovered from limited shovel testing and a $1 \mathrm{x} 1 \mathrm{~m}$ test unit (Unit 1) which revealed a midden deposit. The total weight of the collection is 192.3 grams, and $74(24.3 \%)$ specimens are burned. In general, the sample is highly fragmented but bone surfaces are well preserved. Because of fragmentation, only 44 pieces $(14.4 \%)$ could be specifically identified. Table 23 provides the number of identified specimens (NISP) in the 41CE426 faunal collection, as well as the minimum number of individuals (MNI) by taxon, their preferred habitat, and the percent of the sample represented by each taxon.

Table 23. Summary of Taxonomic Recovery from 41CE426.

\begin{tabular}{lllll}
\hline Taxon & NISP & MNI & Habitat* & Percent \\
\hline Vertebrata (indeterminate) & 29 & - & - & 9.5 \\
Indeterminate fish (Osteichthyes) & 1 & 1 & A & 0.3 \\
Pond Slider (Pseudemys sp.) & 1 & 1 & A & 0.3 \\
Indeterminate turtle (Testudinata) & 6 & - & - & 2.0 \\
Turkey (Meleagris gallopavo) & 4 & 1 & WE & 1.3 \\
White-tailed deer & & & & \\
(Odocoileus virginianus) & 32 & 1 & WE & 10.5 \\
Mammal (large Mammalia) & 231 & - & - & 76.0 \\
\hline Total & 304 & 4 & & 100 \\
\hline
\end{tabular}

*Preferred Habitat (Davis 1978; Schmidly 1983): A=aquatic (rivers, swamps, marshes); W=woodlands (deciduous or pine forests); WE=wooded edges (open meadows, parkland)

Standard zooarchaeological identification techniques were employed in this analysis, using comparative skeletal collections. Attributes that were examined for each of the bone fragments include taxon, element and portion of that element, symmetry, burning, and weight. Unidentifiable specimens were consolidated into two categories: large mammal and indeterminate vertebrate. This analysis is concerned with identifying the general preferences of late 17th century Caddo animal exploitation in the East Texas Pineywoods. The faunal remains came from $0-22 \mathrm{~cm}$ bs in the archaeological deposits (Table 24). They can be considered subsistence debris, although animals only provided a supplement to the Caddo diet; agriculture played a large role in the Caddo life as well by Historic Caddo times.

Despite the high quantity of unidentifiable faunal remains and severe fragmentation, a few inferences can be made about the 41CE426 faunal sample. The fish vertebral fragment compares favorably to a medium-sized bowfin and suggests that aquatic habitats were exploited, possibly the nearby Stone Chimney Creek. Further evidence of the exploitation of aquatic habitats is demonstrated by the identification of the pond slider turtle carapace fragment. The indeterminate turtle shell fragments compare favorably to musk/mud turtle (Kinosternidae sp.) and/or box turtle (Terrapene sp.). The musk or mud turtle prefers habitats near water as well. The box turtle is a slow-moving animal that occurs in woodlands and bottomlands and is easily caught when the occasion arises by passive hunting methods, often by women or children. The turkey occurs as wild fowl in open woodland environments (Robbins et al. 
Table 24. Distribution of 41CE426 Faunal Remains by Provenience (Shovel Test or Unit).

\begin{tabular}{|c|c|c|c|}
\hline $\begin{array}{l}\text { Provenience } \\
(\mathrm{cm} \mathrm{bs})\end{array}$ & Taxon & NISP & $\begin{array}{l}\text { Total NISP } \\
\text { by ST/Unit } \\
\& \text { Level }\end{array}$ \\
\hline ST $1,0-20$ & large mammal & 1 & 1 \\
\hline \multirow[t]{2}{*}{ ST 6, 0-20 } & deer & 5 & \\
\hline & large mammal & 29 & 34 \\
\hline \multirow{3}{*}{ ST $10,0-16$} & fish & 1 & \\
\hline & deer & 2 & \\
\hline & large mammal & 24 & 27 \\
\hline \multirow{2}{*}{ ST $11,0-18$} & deer & 2 & \\
\hline & large mammal & 7 & 9 \\
\hline \multirow[t]{4}{*}{ Unit $1,0-10$} & unidentifiable & 6 & \\
\hline & turtle & 1 & \\
\hline & deer & 4 & \\
\hline & large mammal & 48 & 59 \\
\hline \multirow[t]{6}{*}{ Unit 1, 10-20 } & unidentifiable & 22 & \\
\hline & pond slider & 1 & \\
\hline & turtle & 5 & \\
\hline & turkey & 4 & \\
\hline & deer & 18 & \\
\hline & large mammal & 120 & 170 \\
\hline \multirow[t]{3}{*}{ Unit $1,20-22$} & unidentifiable & 1 & \\
\hline & deer & 1 & \\
\hline & large mammal & 2 & 4 \\
\hline
\end{tabular}

1983), preferring the wooded edges of the Pineywoods in East Texas. The four fragments are probably the remains of a game bird, as the Caddo were known to hunt turkey (Newcomb 1993). One turkey leg bone fragment is burned.

Wooded edges are the preferred habitat of deer. The 32 deer bones are mainly comprised of lower limb bone fragments, but one antler fragment, one vertebral fragment, a complete upper molar, and one tooth fragment were also recovered. It is generally thought that non-meat parts of large game are frequently left at the hunt/kill location and only those body parts with high meat yield or tool value are transported from the hunting area back to the habitation site as distance increases. The recovery of certain elements, or their lack of recovery, can be considered evidence of the procurement strategies that were being practiced. The elements identified in this sample suggest that perhaps the entire carcass was brought to the site for processing. The limb bones provided material necessary for tool manufacturing and food preparation such as marrow extraction. Seven pieces are spirally fractured and six specimens are burned. A femur fragment and one phalange are unfused, indicating an immature individual. Deer is most likely represented by the unidentifiable large mammal bone fragments as well (see Table 23). Fifteen large mammal bones are spirally fractured and 67 pieces are burned. The 29 indeterminate vertebrate remains could represent any taxonomic class, but it is noted in comments accompanying Appendix 1 that they compare favorably to bird or small mammal. 
This faunal sample suggests that aquatic and wooded edges were hunted, but other Caddo faunal assemblages demonstrate that all habitats were exploited for the rich environmental resources of East Texas. Further investigations at 41CE426 could provide additional information as to the subsistence preferences and animal hunting activities of late 17th century Caddo peoples in the upper Neches River basin.

\section{CE428}

41CE428 may be part of 41CE421, located some $60 \mathrm{~m}$ north across a shallow dry drainage gully (see Figure 1b), but the two areas could not be connected by a continuous surface distribution of artifacts. A surface collection resulted in the recovery of four parallel brushed body sherds scattered across a 1500 $\mathrm{m}^{2}(0.375$ acres $)$ sandy rise. Shovel tests are needed to better determine the site boundaries as well as to establish if intact archaeological deposits and features are present on this landform. The brushed sherds indicate that the site dates no earlier than ca. A.D. 1300.

\section{CE424}

41CE424 is located on a sandy slope at the base of an upland landform (see Figure 1b). The site is in a mixed pine/hardwood setting, located $0.9 \mathrm{~km}$ east of Stone Chimney Creek; it s bordered on the north by a dry drainage or gully. Soils are Nacogdoches fine sandy loam (Mowery and Oakes 1958). Five parallel brushed, grog-tempered $(n=2)$, grog-bone-tempered $(n=1)$, and grog-hematite-tempered $(n=2)$ body sherds were found in a cow trail; their recovery indicates that 41CE424 was occupied no earlier than ca. A.D. 1300. No further archaeological investigations have been conducted at this location.

\section{CE425}

41CE425 is located across Stone Chimney Creek from 41CE424 on a sandy upland landform (see Figure 1b). Soils are of the Nacogdoches series. Nine shovel tests, four of which were positive, have an average depth of A-horizon sediments of $27.6 \mathrm{~cm}$. The artifact density is low, approximately 4.0 artifacts per positive shovel test, or approximately 32 artifacts per square meter.

The total number of artifacts from 41CE425 from surface collections and shovel tests include nine ceramic body sherds, six pieces of lithic debris, and one chipped stone graver tool. The small collection of ceramic sherds include seven decorated sherds, five (71.4\%) of which are brushed, one other body sherd has tool punctates, and another has parallel incised lines.

The one tool is a graver made from a non-cortical gray chert flake. The lithic debris includes gray quartzite ( $\mathrm{n}=1$, cortical), gray chert $(\mathrm{n}=1$, non-cortical), brown chert $(\mathrm{n}=2,1$ cortical, 1 non-cortical), and heat-treated red quartzite ( $\mathrm{n}=2$, non-cortical).

\section{CE427}

41CE427 is located on a slope of a sandy upland landform some $75 \mathrm{~m}$ east of Stone Chimney Creek in a pasture setting (see Figure 1b). Soils are of the Nacogdoches series (Mowery and Oakes 1958). Artifacts were collected from the surface in a dirt field road. No shovel tests have been conducted at this location. Artifacts collected from 41CE427 include two brushed, grog-tempered (one also has hematite temper inclusions), body sherds, and seven flakes (five gray chert, non-cortical; one tan chert, non-cortical; and one red heat-treated quartzite, cortical). The occurrence of brushed ceramic sherds suggests the site was not occupied before ca. A.D. 1300. 


\section{CE429}

This site is located where feral hogs had rooted up a portion of a pasture. If not for the hog activity, this site might have been overlooked, because it is located on the back portion of an upland landform some $0.4 \mathrm{~km}$ from Stone Chimney Creek (see Figure 1b). It is bordered on the north by a dry drainage/ gully and on the east by a sharp rocky rise.

From when the site was first located, additional land-clearing activities have resulted in a fairly large surface collection plus artifacts from 34 positive shovel tests. Based on surface observation and the shovel tests, the site covers some $3000 \mathrm{~m}^{2}(0.75$ acres $)$. Shovel tests revealed that the landform has a shallow reddish-brown sandy loam A-horizon, with numerous ironstone concretions, overlying a red crumbly clay B-horizon. No features were detected in the shovel testing, although burned bone occurred in some shovel tests and was also observed on the surface, indicating that there could be intact cooking features or midden deposits present at 41CE429.

A total of 618 artifacts were recovered from 41CE429, including 11 pieces of animal bone and one burned mussel shell fragment (Table 25). As with all the Stone Chimney Creek sites, ceramic sherds dominate the assemblage (94.5\%), with small amounts of lithic debris, chipped stone and ground stone tools, ceramic pipe sherds, and a clay spindle whorl.

Table 25. Artifacts Recovered from $41 \mathrm{CE} 429$.

\begin{tabular}{lll}
\hline Artifact Category & No. & Percent \\
\hline Caddo ceramic sherds & 584 & 94.5 \\
Lithic debris & 14 & 2.3 \\
Possible gun flint & 1 & 0.2 \\
End-side scraper & 1 & 0.2 \\
Ground stone tools & 2 & 0.3 \\
Ceramic pipe sherds & 3 & 0.5 \\
Clay spindle whorl & 1 & 0.2 \\
Burned bone fragments & 11 & 1.8 \\
Burned mussel shell fragment & 1 & 0.2 \\
\hline Totals & 618 & 100 \\
\hline
\end{tabular}

The 584 ceramic sherds from $41 \mathrm{CE} 429$ are comprised of 465 decorated sherds and 119 plain sherds (Table 26). Excluding base sherds, the P/DR ratio is 0.22 , consistent with a Historic Caddo occupation in the Upper Neches River basin. The average sherd thickness is $9.5 \mathrm{~mm}$, suggesting large and durable vessels were in use. About $83 \%$ of the sherds from 41 CE429 have grog temper, another $16.1 \%$ are groghematite tempered, while only $0.8 \%$ have bone temper inclusions.

The 465 decorated sherds from 41CE429 are grouped into nine utility ware decorative classes and two fine ware decorative classes (Table 27). Utility wares comprise $97.4 \%$ of all the decorated sherds from the site, with brushed sherds accounting for $87.7 \%$ of the utility wares.

Among the brushed sherds, by far the most common decoration on them is parallel brushing, as these sherds account for $92 \%$ of all the brushed vessel sherds (Table 28 ). These are probably from the body of brushed jars, and if their orientation could be discerned, it would most likely be that the brushing is vertical on the vessel body. A few other sherds have overlapping, horizontal, or vertical brushed marks. 
Table 26. The Caddo Ceramic Sherd Assemblage from 41CE429.

\begin{tabular}{lll}
\hline Sherd Type & No. & Percent \\
\hline Plain rim & 2 & 0.3 \\
Plain body & 102 & 17.5 \\
Plain base & 15 & 2.6 \\
$\quad 119$ & 20.4 \\
$\quad$ Subtotal, Plain sherds & 12 & 2.1 \\
Decorated fine ware & 453 & 77.6 \\
Decorated utility ware & 465 & 79.6 \\
$\quad$ Subtotal, decorated sherds & 584 & 100 \\
\hline Totals & & \\
\hline
\end{tabular}

Table 27 . Decorated Sherds from 41CE429.

\begin{tabular}{lll}
\hline Decorative Method & $\mathrm{N}$ & Percent \\
\hline Fine Ware & & 1.3 \\
Patton Engraved & 6 & 1.3 \\
Other engraved & 6 & 2.6 \\
$\quad$ Subtotal & 12 & \\
Utility Ware & & 87.7 \\
Brushed & 408 & 2.2 \\
Brushed/tool punctated & 10 & 0.4 \\
Brushed/incised & 2 & 0.2 \\
Brushed/appliquéd & 1 & 3.7 \\
Incised & 17 & 1.1 \\
Punctated & 5 & 0.6 \\
Neck banded & 3 & 0.4 \\
Ridged & 2 & 1.1 \\
Grooved & 5 & 97.4 \\
\multicolumn{1}{c}{ Subtotal } & 453 & 100 \\
\hline Totals & 465 & \\
\hline
\end{tabular}

Brushed/punctated sherds $(\mathrm{n}=10)$ have tool and crescent-shaped punctates through the brushing; one sherd has a row of tool punctates above parallel brushing (Figure 13b-f, Figure 14c, and Figure 15a). The incised sherds $(n=17)$ have simple geometric designs, including parallel incised lines $(n=10)$, opposing incised lines $(n=5)$, and curvilinear incised lines $(n=2)$. There are five Lindsey Grooved sherds with horizontal wide grooves (Figure 15b-c). 
Table 28. Decorative Elements in Brushed Vessel Sherds.

\begin{tabular}{ll}
\hline Decorative Class and Element & N \\
\hline Parallel brushed & 395 \\
Overlapping brushed & 10 \\
Horizontal brushed & 2 \\
Vertical brushed & 1 \\
\hline Total & 408 \\
\hline
\end{tabular}

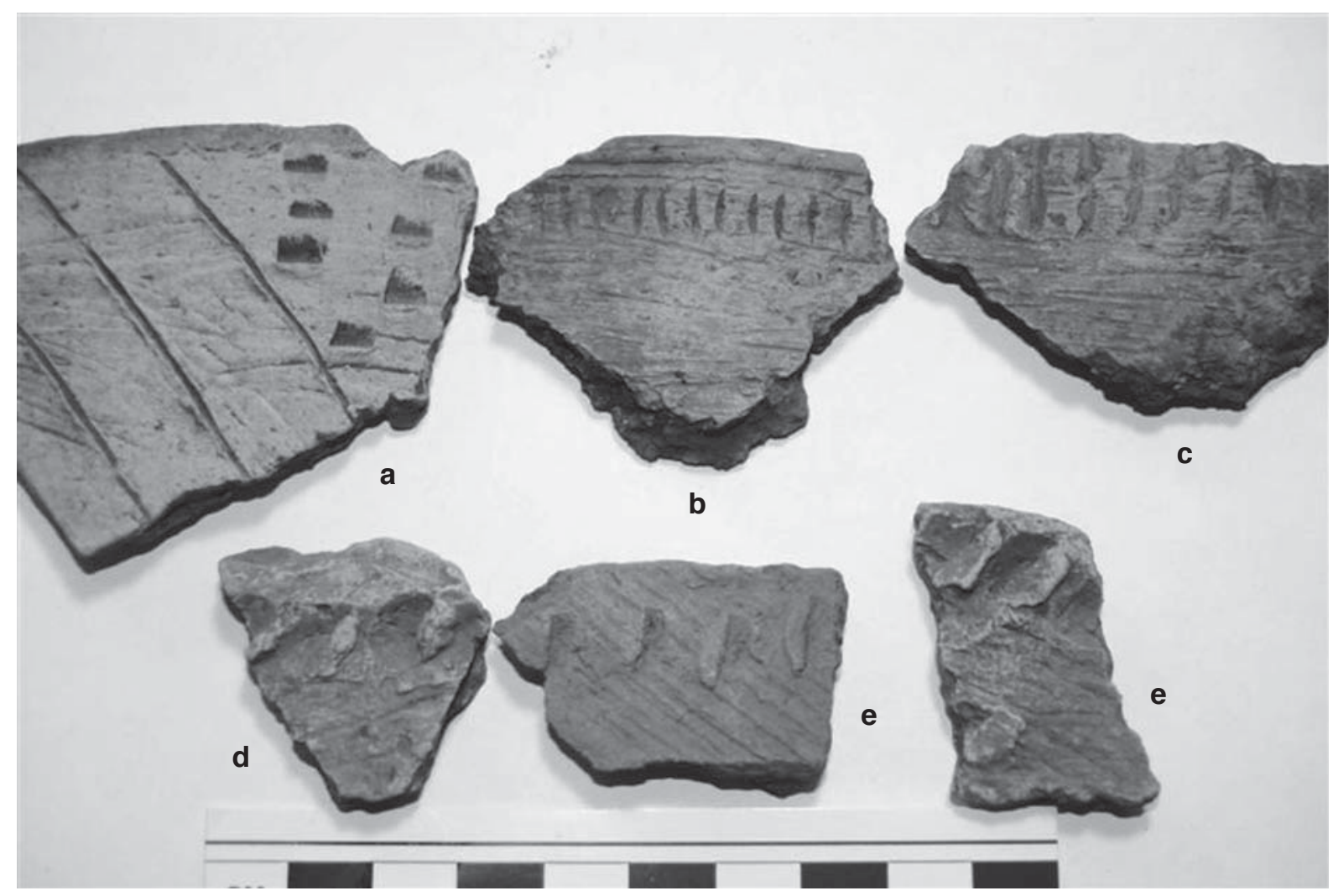

Figure 13. Incised-punctated and brushed-punctated rim and body sherds from 41CE429: a, incised-punctated rim sherd; b-f, brushed-punctated. 


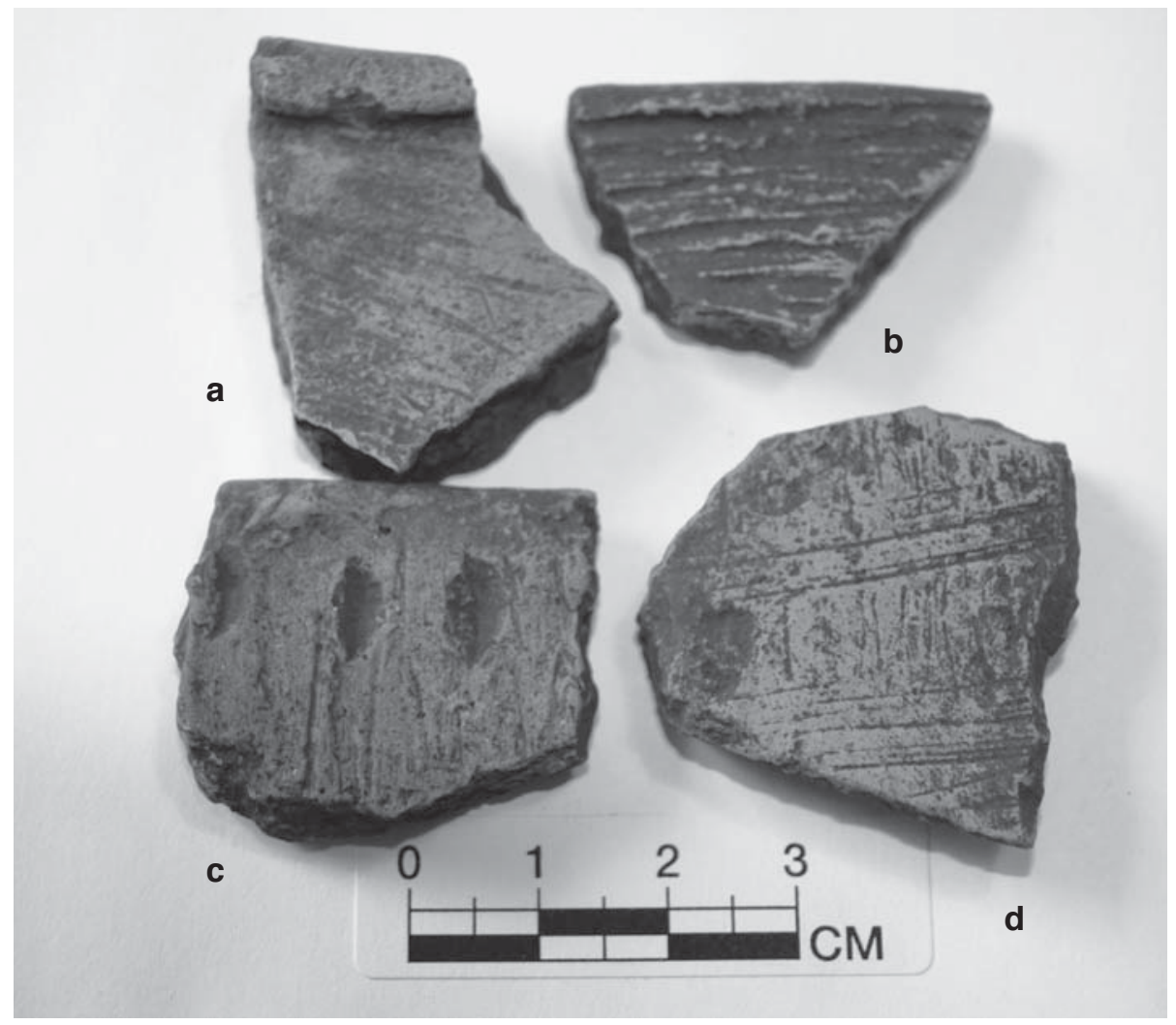

Figure 14. Brushed, brushed-incised, and brushed-punctated rim and body sherds from 41CE429: a-b, brushed rims; c, brushed-punctated rim; d, brushed-incised body sherd.

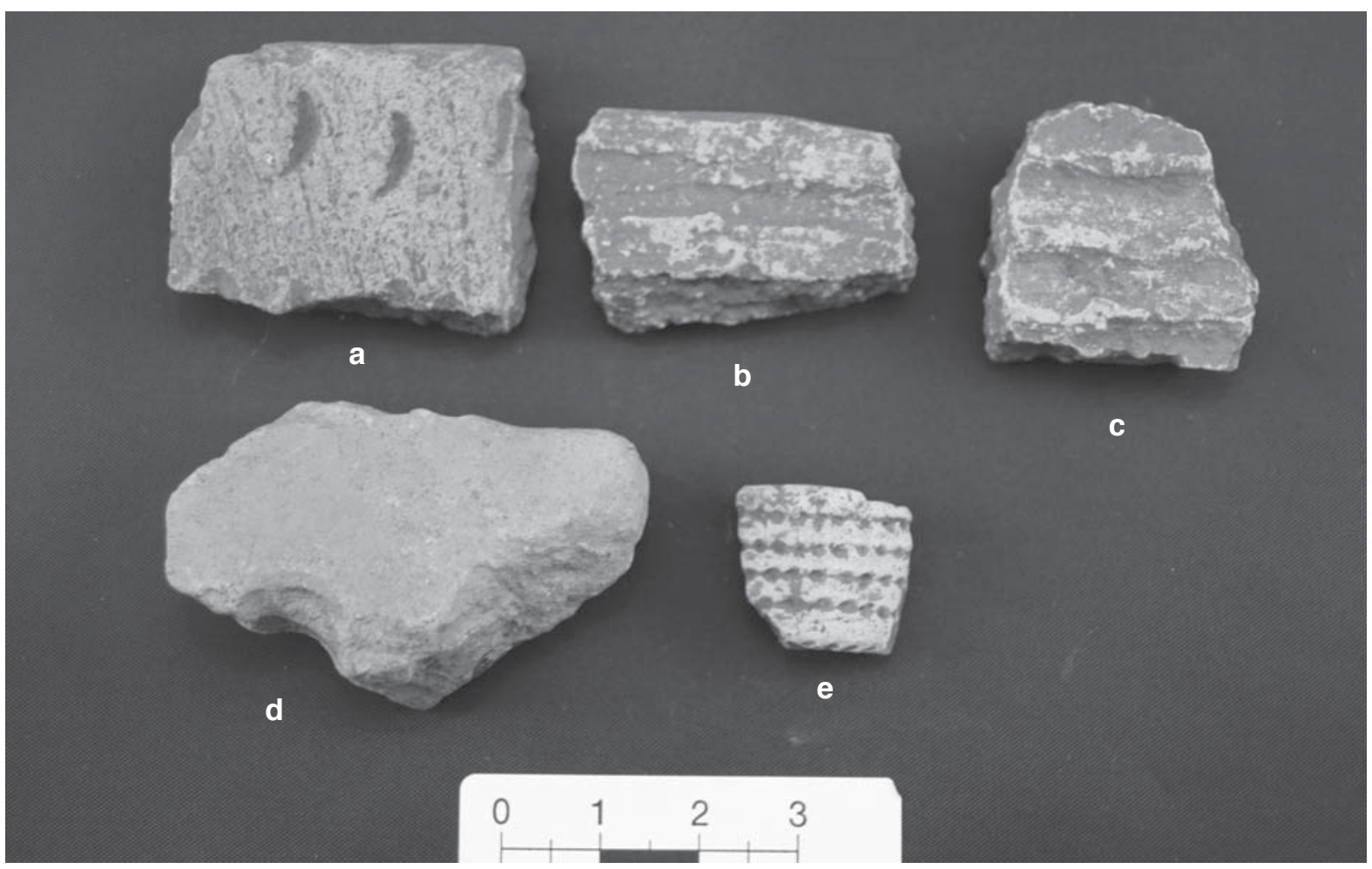

Figure 15. Utility ware sherds and other ceramic artifacts: a, brushed-punctated rim; b-c, Lindsey Grooved body sherds; d, spindle whorl; e, engraved ceramic pipe sherd. 
Engraved sherds $(n=12)$ account for $2.6 \%$ of the total decorated sherds. Patton Engraved sherds $(n=6)$ are dominated by triangular tick marks on horizontal lines (Figure 16a-b). Other engraved elements $(n=6)$ are opposed lines $(n=3)$, straight lines $(n=2)$ and one engraved circle with a cross-arm design.

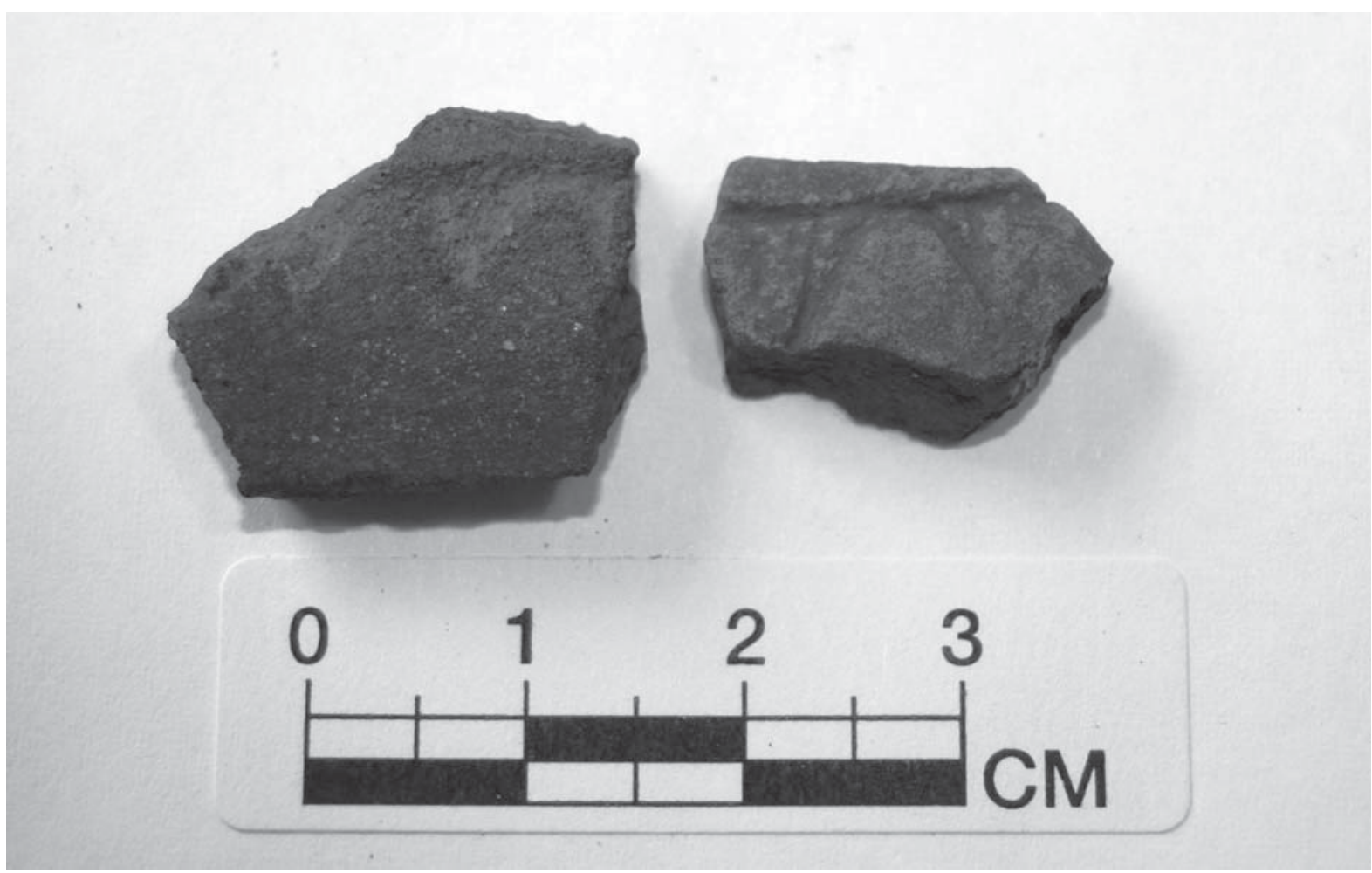

Figure 16. Patton Engraved rim sherds from 41CE429.

There are two plain rims. One, direct with a rounded lip, is from a carinated bowl with an orifice diameter of $14.0 \mathrm{~cm}$. There are 15 plain bases from $41 \mathrm{CE} 429$ that average $13.0 \mathrm{~mm}$ in thickness.

More than 55\% of the sherds from 41CE429 are from vessels that were fired in a low oxygen or reducing environment (Table 29). Of these, about $80 \%$ were subsequently cooled in the open air, leading to a lighter oxidized surface on either one or both vessel surfaces, as well as a thin oxidized zone in the vessel core. A considerable number of sherds are from vessels that were fired and cooled in a high oxygen or oxidizing environment, while only $9.5 \%$ of the sherds were from vessels that were not thoroughly oxidized during firing.

Table 29. Firing Conditions of the Ceramic Sherds from 41CE429.

Firing conditions* Percent

A (oxidizing environment)

B (reducing environment)

F-H (reducing environment, cooled in the open air) 44.2

*Categories are based on Teltser (1993:Figure 2a-h) 
There is one broken spindle whorl from 41CE429 (see Figure 15d). All the surfaces of this base sherd are smoothed and there is a partial drilled hole $(9.5 \mathrm{~mm}$ in diameter) on one broken edge. Dimensions are: length, $47.0 \mathrm{~mm}$; width, $29.8 \mathrm{~mm}$; and thickness, $20.0 \mathrm{~mm}$.

There are three clay pipe sherds in the 41CE429 assemblage. One partial pipe bowl sherd has a flat lip and horizontal engraved lines with tick marks (see Figure 15e), analogous to the decorative elements on Patton Engraved ceramic vessels. A second pipe bowl sherd has incised lines that are vertical on the bowl portion, then the incised lines make a right angle and extend down the pipe stem. The third pipe example is a partial stem that has small reed or cane punctates.

\section{Chipped Stone Tools and Lithic Debris from 41CE429}

Lithic material is very scarce at 41CE429, consisting of 11 flakes, one tested cobble, one scraper, and one possible gunflint. Three gray chert flakes were recovered from shovel tests 13 and 14 between 0-20 cm bs. A fine screen sample from shovel test 18 yielded four small chert pressure flakes. There are four flakes collected from the surface: two gray chert, non-cortical, one with white inclusions; one gray quartzite, cortical; one dark gray chert, non-cortical. The tested cobble is gray quartzite and has two flake removal scars. Dimensions of the cobble are: length, $47.8 \mathrm{~mm}$; width, $30.3 \mathrm{~mm}$; and thickness, $22.5 \mathrm{~mm}$.

There is a small combination end and side scraper in the collection (Figure 17). It is made from a non-cortical tan chert flake. It is $22.0 \mathrm{~mm}$ in length, $11.5 \mathrm{~mm}$ in width, and $2.7 \mathrm{~mm}$ in thickness.

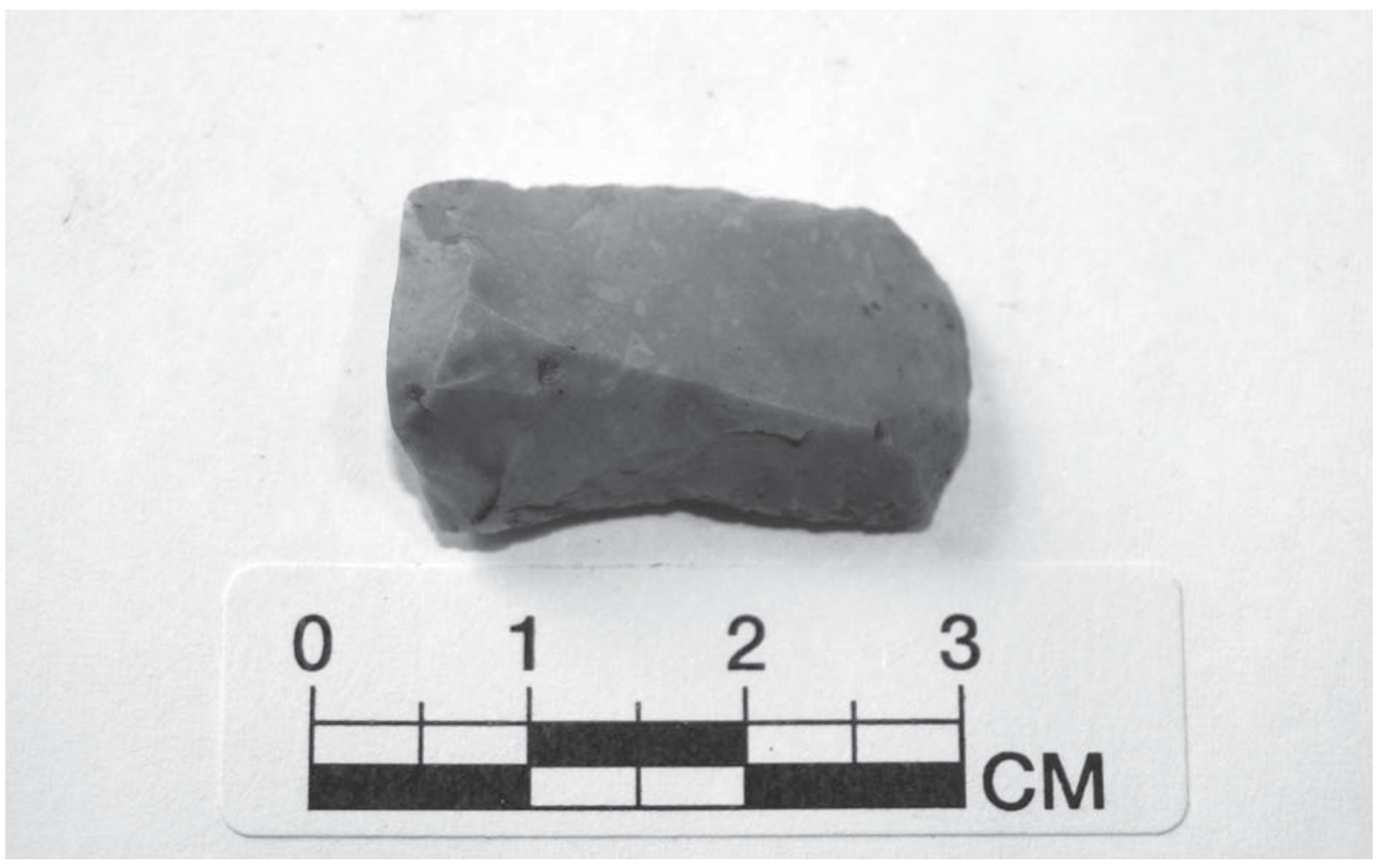

Figure 17. End scraper from 41CE429. 


\section{Gunflint}

There is one possible gunflint from 41CE429. This possible gunflint is wedge-shaped and is made from a light gray chert with cortex at the heel. There is edge retouch on the narrow end of the wedgeshaped piece and evidence of battering. Dimensions are: length, $21.1 \mathrm{~mm}$; width, $23.5 \mathrm{~mm}$; and thickness, $8.2 \mathrm{~mm}$.

According to Jay Blaine, recognized as an authority on gunflints, this example was almost certainly crafted by someone familiar with the shape of European spall forms of gunflints. But he explains the term "possible gunflints" could refer to any flint artifacts from a site that produces a few generally similar sub-rectangular to squared and bifaced examples with at least one retouched straight edge and recognized historic archaeological content. Guns such as the Spanish miquelet could utilize just about any size or shape of a stone that sparks (Jay Blaine, personal communication April 2, 2010). The presence of Patton Engraved sherds and a high percentage of brushed wares at 41CE429 indicate that the site falls in the time period of European contact in this part of East Texas, but more evidence in the form of other trade goods is needed to confirm if this example is actually a gunflint.

\section{Ground Stone Tools}

Two ferruginous sandstone ground stone tools were recovered from 41CE429. One is a nutting stone with a slight concave circular depression on one side. All surfaces have been smoothed. Dimensions are: length, $90.5 \mathrm{~mm}$; width, $80.1 \mathrm{~mm}$; and thickness, $30.5 \mathrm{~mm}$. The second ground stone tool is also a nutting stone. It has a $35.9 \mathrm{~mm}$ diameter depression on one side that is $4.0 \mathrm{~mm}$ deep. Dimensions are: length, $47.8 \mathrm{~mm}$; width, $30.3 \mathrm{~mm}$; and thickness, $34.9 \mathrm{~mm}$.

\section{Faunal Remains}

There were four small, unidentifiable pieces of burned bone recovered from a fine screen sample from shovel test 18 . Seven other small pieces of burned bone were collected from the surface along with one piece of burned mussel shell.

\section{DISCUSSION OF THE STONE CHIMNEY CREEK SITES}

There are good archaeological reasons to believe that the Stone Chimney Creek sites represent part of a Historic Caddo community that was situated on a tributary to the Neches River in the upper Neches River Basin (see Figure 1a). A number of the sites along Stone Chimney Creek contain the kinds of material culture remains that are known to occur on other Historic Caddo sites in this region (Table 30; see also Perttula and Nelson 2007, 2009a, 2009b; Marceaux 2011:164-186, 413-433). The other five sites (41CE422, 41CE424, 41CE425, 41CE427, and 41CE428) have very small artifact samples, and definitive evidence of Historic Caddo occupations at them must await further investigations.

These sites on Stone Chimney Creek represent part of an Upper Neches cluster of Allen phase sites (see Perttula 2007:Figure 1; Marceaux 2011:Figure 9.1) that occur on tributaries of the Neches River. This cluster represents what are believed to be related Historic Caddo sites that occur in close proximity to each other. In historic times, the archaeology of the East Texas Caddo groups living in parts of the Neches-Angelina River basins is associated with the Allen phase, dated from ca. A.D. 1650-1800 or later: "The Allen phase is believed to have developed out of the Frankston phase, and more importantly, to have shared the same form of organization, kinds of inter-group interaction, and settlement patterns" (Story and Creel 1982:34).

Story and Creel (1982:32) have suggested that the Frankston and Allen phase populations were organized in a "weakly hierarchical structure" analogous to the Hasinai confederacy that was in existence by the late 17th-early 18th centuries (see Swanton 1942). Allen phase components are found in the Neches 
Table 30. Study area sites and Historic Caddo archaeological elements present.

\begin{tabular}{llllll}
\hline Site & $\begin{array}{l}\text { Patton } \\
\text { Engraved }\end{array}$ & $\begin{array}{l}\text { Neck- } \\
\text { Banded }\end{array}$ & $\begin{array}{l}\text { Lindsey } \\
\text { Grooved }\end{array}$ & $\begin{array}{l}\text { Possible } \\
\text { King } \\
\text { Engraved }\end{array}$ & $\begin{array}{l}\text { Possible } \\
\text { gunflint }\end{array}$ \\
\hline 41 CE421 & $\mathrm{X}$ & $\mathrm{X}$ & & $\mathrm{X}$ \\
$41 \mathrm{CE} 423$ & $\mathrm{X}$ & & & \\
$41 \mathrm{CE} 426$ & $\mathrm{X}$ & $\mathrm{X}$ & $\mathrm{X}$ & $\mathrm{X}$ & $\mathrm{X}$ \\
$41 \mathrm{CE} 429$ & $\mathrm{X}$ & $\mathrm{X}$ & & \\
\hline
\end{tabular}

$\mathrm{X}=$ present in site artifact assemblages

and Angelina river basins in Cherokee, Anderson, Houston, Rusk, Smith, and Nacogdoches counties (see Cole 1975; Kenmotsu 1992; Perttula and Nelson 2006, 2007; Story 1982, 1995), and usually, but not always, depending in part on the age of the occupation and the access to European trade goods, contain small amounts of European trade goods found in village and burial contexts. Caddo domestic remains at these settlements included a variety of decorated ceramic fine wares (principally Patton Engraved) and utility wares (principally Bullard Brushed, La Rue Neck Banded, and Killough Pinched, usually grog or bone-tempered depending on which Allen phase cluster is under consideration) and with brushed vessel bodies, triangular and stemmed arrow points, elbow pipes (plain and decorated), ground stone tools, and bone tools. These Caddo groups were successful agriculturists.

Marceaux (2011:498-501,507, and Table 10.6) notes that the Upper Neches cluster is best recognized by its ceramic assemblage character, featuring a very high rate of grog temper use and a correspondingly low rate of bone temper use, as well as a dominance of bushed pottery sherds among all the decorated sherds. Fine wares are primarily Patton Engraved. The Stone Chimney Creek sites with Historic Caddo occupations conform to these expectations, as only $0.8-6.7 \%$ of the sherds from 41CE421, 41CE423, 41CE426, and 41CE429 are bone-tempered, and between 87.7-91.9\% of the decorated sherds are brushed. Patton Engraved sherds are found in each of these four sites.

From the comparisons of ceramic attribute data on Caddo sites in the region, a frequency seriation has been constructed, with six different groups of upper Neches River ceramic assemblages identified that can be seriated (see O'Brien and Lyman 1999) from oldest (Group VI) to youngest (Group I). The Stone Chimney Creek sites are assigned to Group I (Table 31). These groups seem to reflect temporal changes due to the high frequency of Late Caddo Frankston phase decorated types, such as Poynor Engraved, Maydelle Incised, Bullard Brushed, Hume Engraved, and engraved effigy vessels, that are found in the Groups II-IV sites (corresponding to the early, middle, and late parts of the Frankston phase) - as well as Patton Engraved sherds from sites in Group I-and the occurrence of Early and Middle Caddo types such as Canton Incised, Dunkin Incised, Holly Fine Engraved, and Pennington Punctated-Incised in the Group V and VI upper Neches River sites, as well as cf. Poynor Engraved sherds (i.e., early forms of Poynor Engraved) in components in Group V, including Lang Pasture (Perttula 2011a) and 41SM404 (Perttula 2011c).

This particular seriation, with three different temporal groupings of Frankston phase sites and one group of Allen phase sites, is also supported by differences in: (a) the proportions of Poynor Engraved varieties, Patton Engraved, engraved effigy vessels, Maydelle Incised, La Rue Neck Banded, and Bullard Brushed in upper Neches River Caddo burials (Perttula 2011a), (b) differences in the relative frequencies of common vessel forms in Poynor and Patton Engraved vessels (Kleinschmidt 1982:Figure 24), as well as (c) the occurrence of European trade goods. Corbin (2007) considers the Group I-IV Caddo sites part of an upper Neches River cluster that represents a conglomeration of constituent groups that share a broadly similar socio-political organization through time and space (see Story and Creel 1982:30-34). 
Table 31. Comparative sherd assemblage data from selected upper Neches River basin Caddo sites (modified from Perttula 2011c:Table 23).

\begin{tabular}{llllll}
\hline Site & $\begin{array}{l}\text { No. of Dec. } \\
\text { Sherds }\end{array}$ & $\%$ Brushed* $* \begin{array}{l}\text { \%bone- } \\
\text { temper }\end{array}$ & $\begin{array}{l}\text { \%Wet-paste } \\
\text { decorations }\end{array}$ & P/DR & $\begin{array}{l}\text { Brushed/Wet } \\
\text { paste ratio }\end{array}$ \\
\hline
\end{tabular}

GROUP I (post-A.D. 1650, Allen phase, Historic Caddo, with Patton Engraved) ( *Stone Chimney sites with Patton Engraved)

$\begin{array}{lllllll}* 41 \mathrm{CE} 426 & 160 & 91.9 & 1.0 & 5.0 & 0.23 & 18.4 \\ * 41 \mathrm{CE} 423 & 97 & 91.8 & 6.7 & 6.2 & 0.29 & 14.8 \\ * 41 \mathrm{CE} 421 & 2353 & 89.5 & 5.4 & 7.8 & 0.28 & 8.5 \\ * 41 \mathrm{CE} 429 & 465 & 87.7 & 0.8 & 9.7 & 0.22 & 9.07 \\ \text { Pine Snake } & 305 & 85.2 & 5.7 & 8.8 & 0.51 & 9.63 \\ \text { Blue Branch } & 49 & 84.0 & ? & 6.1 & 0.57 & 13.67 \\ 41 \mathrm{CE} 354 & 474 & 82.7 & 3.1 & 8.9 & 0.20 & 8.14\end{array}$

GROUP II (late Frankston phase, ca. A.D. 1560-1650)

$\begin{array}{lllllll}\text { 41HE22 } & 228 & 85.5 & ? & 7.5 & 0.62 & 11.4 \\ \text { Henry Lake } & 188 & 81.9 & 3.2 & 7.3 & 0.48 & 11.0 \\ \text { Debro } & 311 & 80.0 & ? & 10.3 & 0.14 & 7.75 \\ \text { 41SM91 } & 179 & 82.7 & ? & 13.4 & 0.55 & 6.17 \\ \text { A. C. Saunders } & 5750 & 75.2 & 15.5 & 14.2 & 0.21 & 5.30 \\ \text { William Sherman } & 525 & 75.8 & ? & 16.2 & 0.44 & 4.68\end{array}$

GROUP III (middle Frankston phase, ca. A.D. 1480-1560)

$\begin{array}{lllllll}\text { Forest Drive } & 1693 & 68.6 & ? & 21.9 & 0.56 & 3.12 \\ \text { Halbert } & 1757 & 65.8 & 2.6 & 26.3 & 0.70 & 2.51 \\ \text { Woldert } & 1730 & 62.7 & 0.0 & 28.8 & 0.72 & 2.19 \\ \text { Ferguson } & 4116 & 60.8 & <1.0 & 27.9 & 0.61 & 2.17\end{array}$

GROUP IV (early Frankston phase, ca. A.D. 1400-1480)

$\begin{array}{lllllll}\text { Tomato Patch } & 912 & 49.2 & ? & 41.7 & 1.50 & 1.21 \\ \text { 41SM88 } & 95 & 37.9 & ? & 49.5 & 1.53 & 0.76 \\ \text { 41AN38+ } & 2435 & 35.9 & 6.7 & 38.0 & 1.40 & 0.91 \\ \text { Mitchell, Area D } & 54 & 32.1 & 0.0 & 33.3 & 1.37 & 1.50\end{array}$

GROUP V (Middle Caddo period, ca. A.D. 1200-1400)

$\begin{array}{lllllll}41 \mathrm{SM} 404 & 446 & 16.0 & 8.5 & 60.7 & 1.73 & 0.26 \\ 41 \mathrm{SM} 73 & 165 & 26.1 & ? & 72.7 & 2.61 & 0.37\end{array}$


Table 31. Comparative sherd assemblage data from selected upper Neches River basin Caddo sites (modified from Perttula 2011c:Table 23), cont.

\begin{tabular}{lcccccc}
\hline Site & $\begin{array}{l}\text { No. of Dec. } \\
\text { Sherds }\end{array}$ & \% Brushed* & $\begin{array}{l}\text { \%bone- } \\
\text { temper }\end{array}$ & $\begin{array}{l}\text { \%Wet-paste } \\
\text { decorations }\end{array}$ & P/DR & $\begin{array}{l}\text { Brushed/Wet } \\
\text { paste ratio }\end{array}$ \\
\hline White Mule & 1404 & 18.5 & 1.5 & 63.7 & 2.61 & 0.29 \\
41HE139 & 40 & 17.5 & 8.1 & 65.0 & 2.51 & 0.33 \\
Broadway, Z1/2 & 256 & 10.9 & 28.8 & 70.0 & 3.97 & 0.16
\end{tabular}

GROUP VI (likely Early Caddo period, ca. A.D. 1000-1200)

$\begin{array}{lllllll}\text { Broadway, Z3 } & 155 & 9.7 & 32.3 & 73.5 & 3.80 & 0.13 \\ \text { Mitchell, Areas A-C } & 56 & 1.3 & 12.0 & 65.7 & 1.71 & 0.03 \\ \text { 41SM87 } & 36 & 0.0 & ? & 69.4 & 4.44 & 0.00\end{array}$

The following five sites from Stone Chimney Creek did not have Patton Engraved sherds or a robust enough sample to place in a Group with any confidence

\begin{tabular}{lllllll}
41 CE422 & 26 & 84.6 & 4.5 & 15.4 & 0.42 & 5.5 \\
41 CE425 & 7 & 71.4 & - & - & 0.29 & - \\
41 CE424 & 5 & 100.0 & - & - & - & - \\
41 CE428 & 4 & 100.0 & - & - & - & - \\
41 CE427 & 2 & 100.0 & - & - & - & - \\
\hline
\end{tabular}

$\mathrm{P} / \mathrm{DR}=$ plain/decorated sherd ratio; *\% brushed represents the percentage of brushed sherds among all the decorated sherds; + combines sherd samples from northern and southern block excavation areas.

These comparisons of the composition of upper Neches River basin Caddo decorated sherd assemblages - and the temporal ordering and cultural affiliations they imply - are based on the percentage of brushed sherds in the decorated sherd sample, the percentage of bone temper in the assemblages, the percentage of wet-paste decorations other than brushing (i.e., incised, punctated, appliqued, neck-banded, etc.), the plain/decorated ratio (P/DR), and the brushed sherd/wet paste decorated sherd ratio (Perttula 2007). It has been shown repeatedly in Caddo ceramic studies in East Texas that the proportion of brushed sherds in decorated sherd assemblages steadily increases through time, beginning after ca. A.D. 1250, during the occupation of the Group V Caddo sites. In the well-dated A.D. 1320-1400 Middle Caddo component (the northern area) at the Lang Pasture site (41AN38), brushed sherds comprise $26 \%$ of the utility wares (see Table 31). Brushed sherds comprise between 10.9-26.1\% of the decorated sherds in Group V sites, and wet-paste sherds (i.e., incised, punctated, etc.) account for between 50.3-72.7\% of the decorated sherds in these assemblages. P/DR values range from 1.73-3.97 (see Table 31). By the early 15th century A.D., however, Caddo potters in the upper Neches River basin began to manufacture considerable numbers of jars with brushed vessel bodies and rims (Perttula 2011b), and by Historic Caddo times, more than $85 \%$ of the decorated sherds in upper Neches River basin sites are brushed (see Table 31). The fact that the proportion of brushed sherds is higher in the Stone Chimney Creek sites than any other Group I sites, and the P/DR values are very low (0.22-0.29), strongly suggests that the Stone Chimney Creek sites are the youngest known Historic Caddo sites in the upper Neches River cluster.

The ceramic assemblages summarized in Table 31, and those from nearby sites that have been recently analyzed in the upper Neches River basin (41CE324, see Perttula and Middlebrook [2009]; and 
41HE337 in the upper Caddo Creek basin, see Perttula [2009]), especially those that date to Frankston phase times (Groups II-IV), share several characteristics that make clear the character of an upper Neches River basin Caddo ceramic tradition that developed from ca. A.D. 1400 to the late 17th to early 18th century. The decorated and plain sherd assemblages in these Frankston and Allen phase sites are (1) almost exclusively grog-tempered; bone-tempered pottery generally comprises less than $6 \%$ of the sherds, where that information is available; (2) brushed utility ware pottery dominates the decorated sherd assemblages, accounting for between 32-92\% of all the decorated pottery (Perttula 2011a:Figure 6-68 and Table 6-38); (3) fine ware vessel sherds generally account for less than $10 \%$ of the decorated sherds, and their frequency decreases through time; (4) wet paste decorations on sherds are also more abundant than fine wares, accounting for between 5-49.5\% of the decorated sherds, by site, and again decreasing in frequency through time; and (5) plain to decorated sherd ratios (P/DR) range from only $0.14-2.25$, with most of the sites having P/DR values less than 1.53 for the ca. A.D. 1400-1480 Caddo sites, less than 0.72 for the ca. A.D. 1480-1650 Caddo sites, and less than 0.30 for the Historic Caddo Allen phase sites. This indicates that Lake Palestine area Caddo sites dating after ca. A.D. 1400 did not have many plain ware vessels. Generally speaking, the lower the P/DR value, the higher the proportion of brushed sherds in the Lake Palestine ceramic assemblages, and the younger the age of the ceramic assemblage. The engraved fine wares are Poynor Engraved and Hood Engraved in Frankston phase sites, and Patton Engraved, Hume Engraved, and King Engraved in Allen phase sites. By the late 17th century, Caddo sites in the upper Neches River basins have ceramic assemblages where brushed sherds account for more than $82 \%$ of the decorated sherds (see Table 31).

In summary, it appears to be the case that the Stone Chimney Creek sites were occupied in the late 17th-early 18th century A.D., during the early part of the Historic Caddo period. This temporal interval is supported by (a) the use of distinctive decorated elbow pipes, (b) a very high proportion of brushed utility wares, (c) few other kinds of decorated utility wares, but those that are present are the same range of types documented in other upper Neches River cluster sites (see Marceaux 2011:164-186, 413-433), and (d) the range of engraved fine ware sherds, which are from vessels with elements and motifs that compare favorably with Patton Engraved and King Engraved, a recently defined Historic Caddo fine ware type.

The groups who during the Allen phase occupied parts of the Neches and Angelina river basins were direct ancestors of the Hasinai tribes. Some of these tribes were living in or near the Spanish missions established on the El Camino Real de los Tejas (originally a Caddo trail) in the region between ca. 16911772, and they continued to maintain residence there until the 1830s (Barr 2011:21-29 and Figure IV). There were no Spanish missions established in the upper Neches River, however, as the area was well north of the Camino Real, and there is no available ethnographic or historical information (see Swanton 1942) concerning either the tribal identity of the Caddo groups that lived in the upper Neches River basin in historic times, or how long they continued to reside in the upper Neches after sustained European contact (after ca. A.D. 1720).

The archaeological findings from various Allen phase sites in the upper Neches River basin, including several sites in Anderson County (among them 41AN184, Perttula 2010) that have European trade goods, indicate that Caddo groups lived in this part of East Texas until at least the mid-18th century, if not later. A 1744 map by Bellin (Figure 18) may provide a clue to the tribal identity of the upper Neches River Caddo groups that occupied sites in the Upper Neches cluster.

This map locates the Pays des Cenis or the territory of the Hasinai Caddo in East Texas, including the Teijas (Tejas), Assinais (Hasinai), and Naouadiches in the Neches and Angelina River basins. It also shows the route of the Camino Real de los Tejas as it bisects the territory of these Caddo groups, and locates other Caddo groups - the Nacanne and Nondaque - well north of the Camino Real and on lands between the Neches and Trinity rivers. Based on the close similarity in the spelling of the tribal name, the Nondaque living on what appears to be the upper Neches according to the Bellin map (see Figure 18) may be related to the Nadaco (and then later Anadarko) tribe of the later 18th and early 19th centuries who lived in the upper Angelina and in the middle Sabine river basins. Thus, it is certainly possible that 


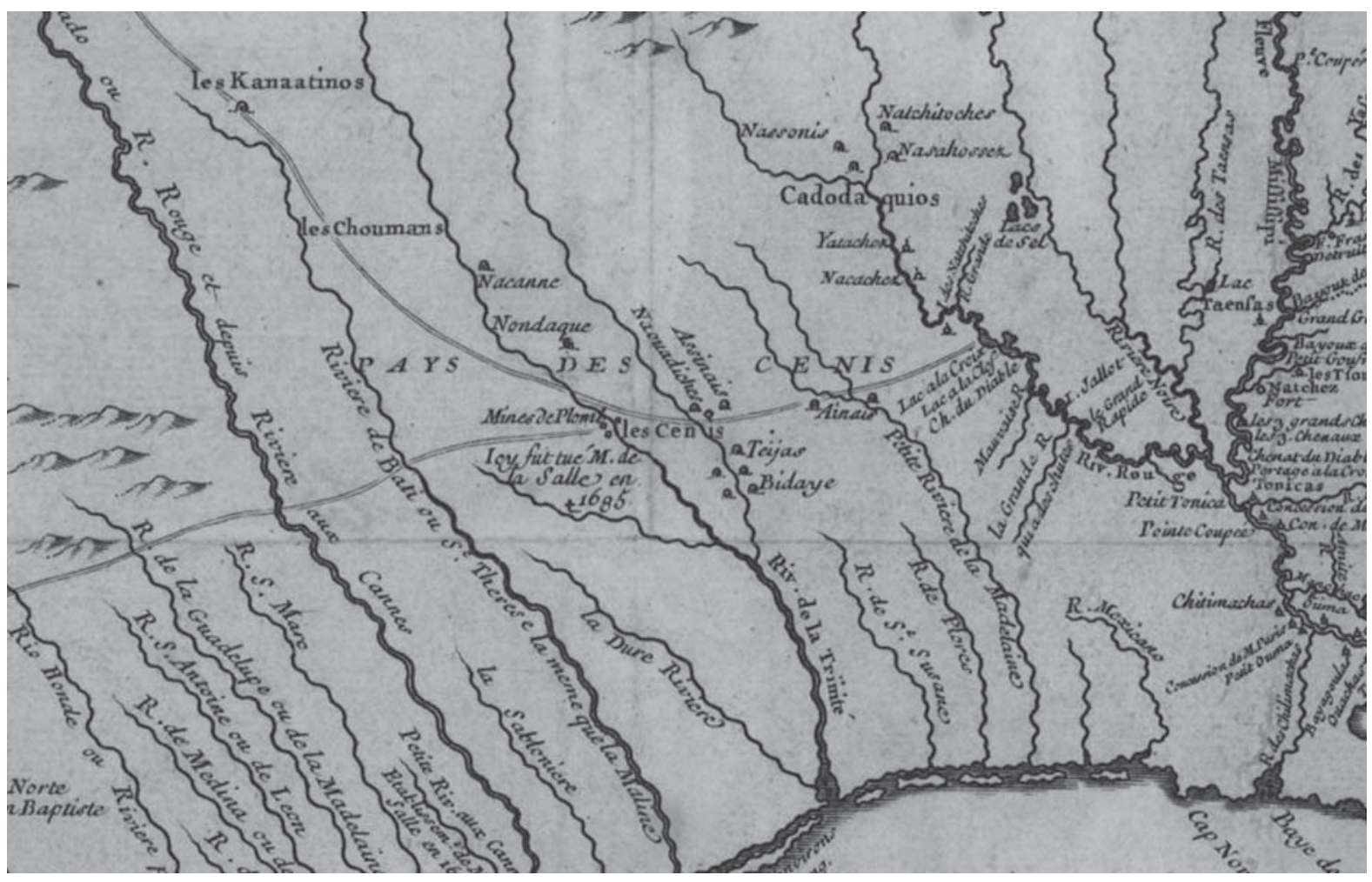

Figure 18. Detail of the 1744 Bellin map showing Pays des Cenis or Hasinai Caddo in East Texas, including the Teijas, Assinais, and Naouadiches in the Neches and Angelina River basins, the route of the Camino Real de los Tejas, and other Caddo groups (Nacanne and Nondaque) well north of the Camino Real and on lands between the Neches and Trinity rivers.

some of the Caddo living in the late 17th-early 18th century in this part of the region represent an ancestral Nadaco or Anadarko Caddo group that once lived in the upper Neches River basin. The Nacanne or Nacachau (see Carter 1995:70) lived upstream from the Nondaque in the Neches River basin (see Figure 18), but they are a poorly known tribe in the Hasinai Confederacy. Campbell (1996:922) indicates that they "lived in Eastern Texas during the late seventeenth and early eighteenth centuries. Their settlements were east of the Neches River in the area now occupied by Cherokee County." After that time, they apparently became part of one or more neighboring Hasinai tribes (Campbell 1996:922). As with the Nondaque, it is quite possible that Caddo communities or townships (see Barr 2011:Figure IV) living in the late 17th-early 18th century in this part of the region represent an ancestral Nacanne or Nacachau Caddo group that once lived in the upper Neches River basin.

\section{ACKNOWLEDGEMENTS}

We would like to thank John and Greta Faulkinberry for allowing the study of their collections and permission for Mark Walters to roam around on their property. Bo Nelson assisted with the surveys, surface collections, and more intensive investigations at 41CE426. Jay Blaine made helpful comments concerning gunflints. Shawn Marceaux contributed Figures 1a-1b for the article. 


\section{REFERENCES CITED}

Anderson, K. M., K. Gilmore, O. R. McCormick, III, and E. P. Morenon

1974 Archaeological Investigations at Lake Palestine, Texas. Contributions in Anthropology No. 11. Department of Anthropology, Southern Methodist University, Dallas.

Barr, J.

2011 Geographies of Power: Mapping Indian Borders in the "Borderlands" of the Early Southwest. William and Mary Quarterly 68(1):5-46.

Campbell, T. N.

1996 Nacachau Indians. In The New Handbook of Texas, Volume 4, edited by R. Tyler, p. 922. Texas State Historical Association, Austin.

Carter, C. E.

1995 Caddo Indians: Where We Come From. University of Oklahoma Press, Norman.

Cole, N. M.

1975 Early Historic Caddoan Mortuary Practices in the Upper Neches Drainage, East Texas. Master's thesis, Department of Anthropology, The University of Texas at Austin.

Corbin, J. E.

2007 Cultural Diversity in the Southern Caddo Region. Journal of Northeast Texas Archaeology 26:1123.

Davis, W. B.

1978 The Mammals of Texas. Bulletin No. 41, revised. Texas Parks and Wildlife Department, Austin.

Johnson, L., Jr.

1961 An Archeological Survey of Blackburn Crossing Reservoir on the Upper Neches River. Bulletin of the Texas Archeological Society 31:213-238.

Kenmotsu, N. A.

1992 The Mayhew Site: A Possible Hasinai Farmstead, Nacogdoches County, Texas. Bulletin of the Texas Archeological Society 63:135-173.

Kleinschmidt, U. K. W.

1982 Review and Analysis of the A. C. Saunders Site, 41AN19, Anderson County, Texas. Master's thesis, Department of Anthropology, The University of Texas at Austin.

Marceaux, P. S.

2011 The Archaeology and Ethnohistory of the Hasinai Caddo: Material Culture and the Course of European Contact. Ph.D. dissertation, Department of Anthropology, The University of Texas at Austin.

Middlebrook, T.

2008 The J. T. King Site (41NA15). Paper presented at the 2008 East Texas Caddo Research Group meeting, Nacogdoches.

Mowery, I. C. and H. Oakes

1958 Soil Survey, Cherokee County, Texas. Soil Conservation Service, and Texas Agricultural Experiment Station. U.S. Government Printing Office, Washington D.C. 
Newcomb, W. W., Jr.

1993 The Indians of Texas from Prehistoric to Modern Times. $2^{\text {nd }}$ Edition. University of Texas Press, Austin.

O'Brien, M. J. and R. L. Lyman

1999 Seriation, Stratigraphy, and Index Fossils: The Backbone of Archaeological Dating. Kluwer Academic/Plenum Publishers, New York.

Perttula, T. K.

2007 One Attempt at Defining Allen Phase Ceramic Subclusters. Journal of Northeast Texas Archaeology 26:77-81.

2009 Late Caddo Ceramics from 41HE337 in Henderson County, Texas. Journal of Northeast Texas Archaeology 29:53-57.

2010 Archaeological Findings from an Historic Caddo Site (41AN184) in Anderson County, Texas. Journal of Northeast Texas Archaeology 33:53-61.

2011a The Ceramic Artifacts from the Lang Pasture Site (41AN38) and the Place of the Site within an Upper Neches River Basin Caddo Ceramic Tradition. In Archeological Investigations at the Lang Pasture Site (41AN38) in the Upper Neches River Basin of East Texas, assembled and edited by

T. K. Perttula, D. B. Kelley, and R. A. Ricklis, pp. 145-320. Report No. 129. Archeological Studies Program, Environmental Affairs Division, Texas Department of Transportation, Austin.

2011b The Pipe Site, a Late Caddo Site at Lake Palestine in Anderson County, Texas. Journal of Northeast Texas Archaeology 35:47-80.

2011c Ceramic Analysis. In National Register of Historic Places Eligibility Testing of Site 41SM404 Within TxDOT's Tyler District, Smith County, Texas, by M. A. Nash, T. K. Perttula, and L. W. Ellis, pp. 49-106. Document No. 110055. PBS\&J, Austin.

Perttula, T. K., with contributions by D. E. Wilson and M. Walters

2006 A Study of the Buddy Calvin Jones Collection from Northeast Texas Caddo Sites. Special Publication No. 6. Friends of Northeast Texas Archaeology, Pittsburg and Austin.

Perttula, T. K. and T. Middlebrook

2009 Prehistoric Caddo Ceramics from the Henry Lake Site (41CE324), Cherokee County, Texas. Journal of Northeast Texas Archaeology 29:9-21.

Perttula, T. K. and Bo Nelson

2006 Test Excavations at Three Caddo Sites at Mission Tejas State Park, Houston County, Texas. Report of Investigations No. 76. Archeological \& Environmental Consultants, LLC, Austin.

2007 Archeological Survey Investigation and Test Excavation at 41 CE354 at the North and South Lake area of the H.R.C. Cherokee Tree Farm, L.P. Project, Cherokee County, Texas. Report of Investigations No. 80. Archeological \& Environmental Consultants, LLC, Austin.

2009a Archeological Survey of Additional Lands of the H.R.C. Cherokee Tree Farm, L. P. Project, Cherokee County, Texas. Internal document. Report of Investigations No. 96. Archeological \& Environmental Consultants, LLC, Austin.

2009b Archeological Survey of 361.3 Acres of the H.R.C. Cherokee Tree Farm, L. P. Project in the Flat Creek Valley, Cherokee County, Texas. Internal document. Report of Investigations No. 98. Archeological \& Environmental Consultants, LLC, Austin.

Perttula, T. K., L. L. Bush, L. Schniebs, T. Middlebrook, and P. S. Marceaux

2010 An Early Historic Caddo Farmstead at the Henry M. Site (41NA60) in Nacogdoches County, Texas. Stephen F. Austin State University Press, Nacogdoches. 
Perttula, T. K., B. Nelson, and M. Walters

2010 Archeological Investigations at the Pine Snake Site, an Allen Phase Settlement on Flat Creek in Northwestern Cherokee County, Texas. Letter Report No. 234. Archeological \& Environmental Consultants, LLC, Austin.

2011 Archeological Survey Investigations to Identify 17th-early 19th Century Caddo Sites along El Camino Real de los Tejas National Historic Trail in East Texas. Archeological \& Environmental Consultants, LLC, Austin.

Robbins, C. S., B. Bruun, and H. S. Zim

1983 A Guide to Field Identification: Birds of North America. Revised edition by Western Publishing, Racine, Wisconsin.

Schmidly, D. J.

1983 Texas Mammals East of the Balcones Fault Zone. Texas A\&M University Press, College Station.

Story, D. A. (editor)

1982 The Deshazo Site, Nacogdoches County, Texas, Vol. 1. Texas Antiquities Permit Series No. 7. Texas Antiquities Committee, Austin.

1995 The Deshazo Site, Nacogdoches County, Texas, Volume 2: Artifacts of Native Manufacture. Studies in Archeology 21. Texas Archeological Research Laboratory, The University of Texas at Austin.

Story, D. A. and D. G. Creel

1982 The Cultural Setting. In The Deshazo Site, Nacogdoches County, Texas, Volume 1, edited by D. A. Story, pp. 20-34. Texas Antiquities Permit Series No. 7. Texas Antiquities Committee, Austin.

Suhm, D. A. and E. B. Jelks (editors)

1962 Handbook of Texas Archeology: Type Descriptions. Special Publication No. 1, Texas Archeological Society, and Bulletin No. 4, Texas Memorial Museum, Austin.

Swanton, J. R.

1942 Source Material on the History and Ethnology of the Caddo Indians. Bulletin 132. Smithsonian Institution, Bureau of American Ethnology, Washington, D.C.

Teltser, P. A.

1993 An Analytic Strategy for Studying Assemblage-Scale Ceramic Variation: A Case Study from Southeast Missouri. American Antiquity 58(3):530-543. 



\section{APPENDIX I, INVENTORY OF FAUNAL REMAINS FROM 41CE426}

\section{LeeAnna Schniebs}




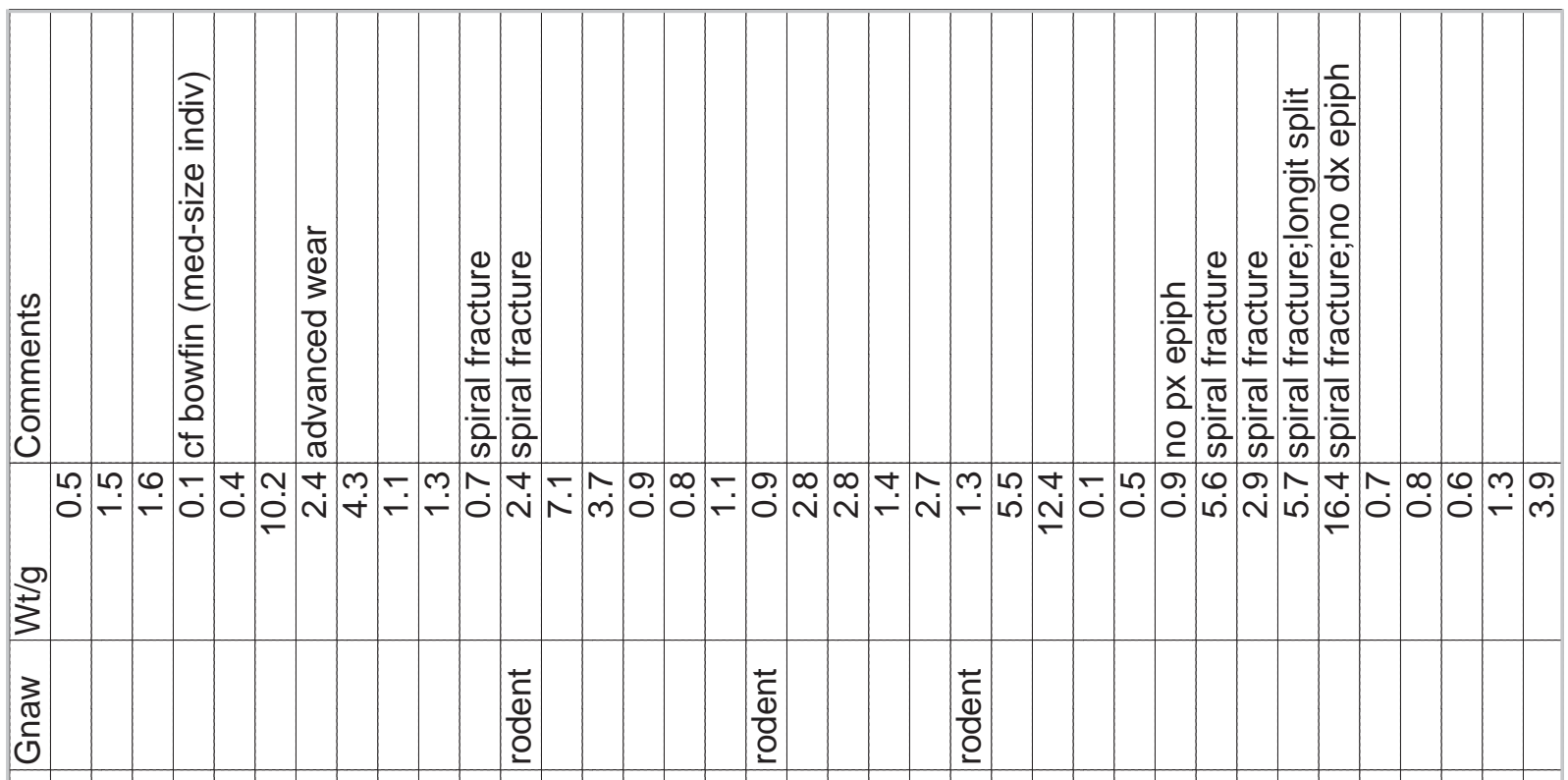

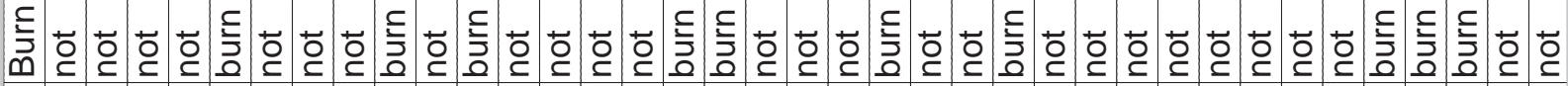

\begin{tabular}{|l|}
\hline 8 \\
\hline 8 \\
\hline 0 \\
\hline 0 \\
\hline 0
\end{tabular}

$\frac{0}{5} \quad<$

$\varangle \quad-\propto$

$\simeq \llbracket \llbracket$ $\underline{\underline{\varepsilon}}$

$\simeq \simeq$

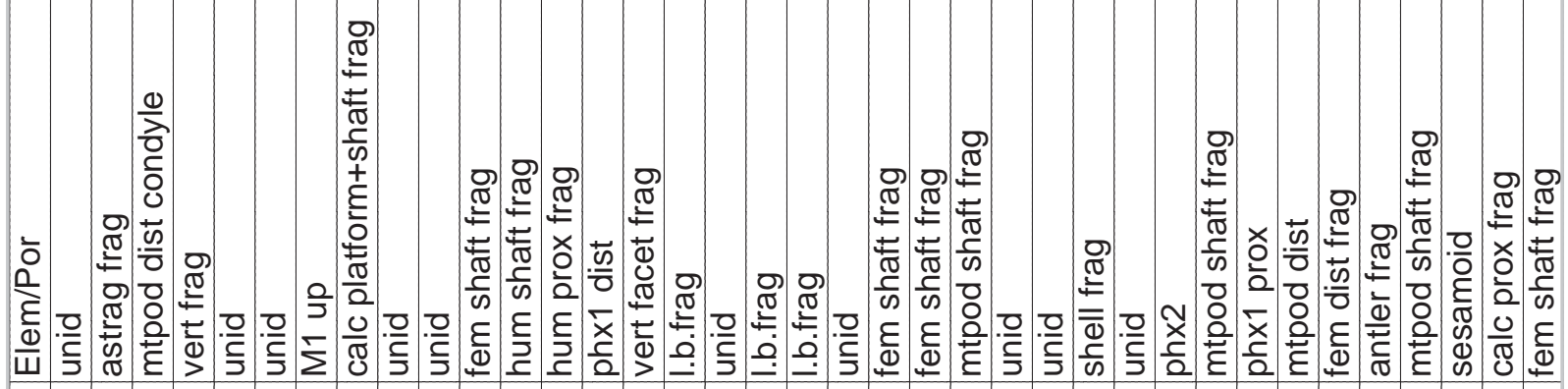

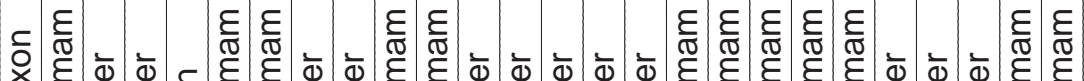

メ

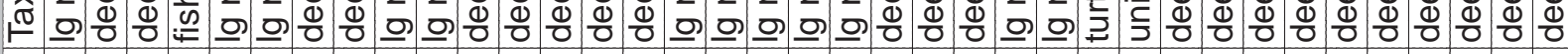

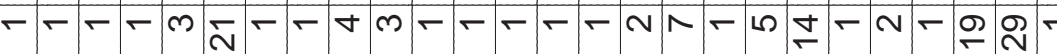

$\overrightarrow{0}$

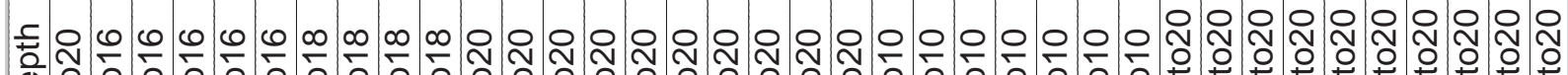

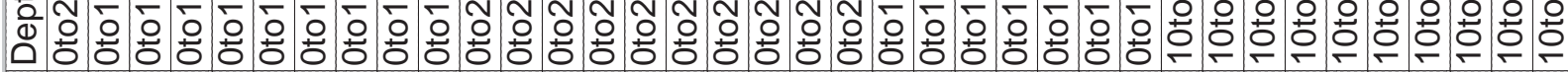

:

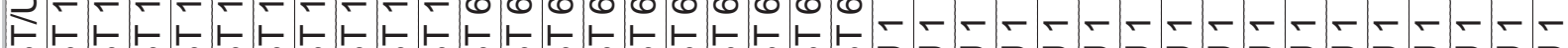

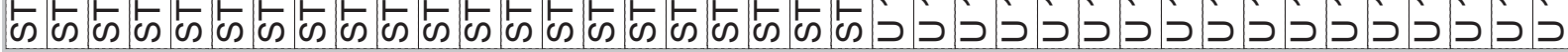



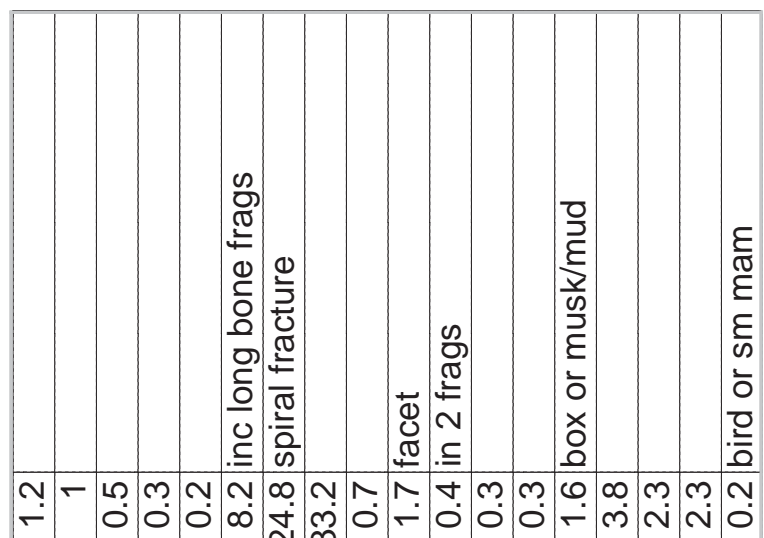

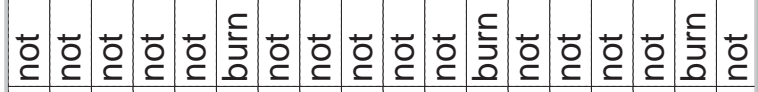

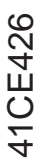
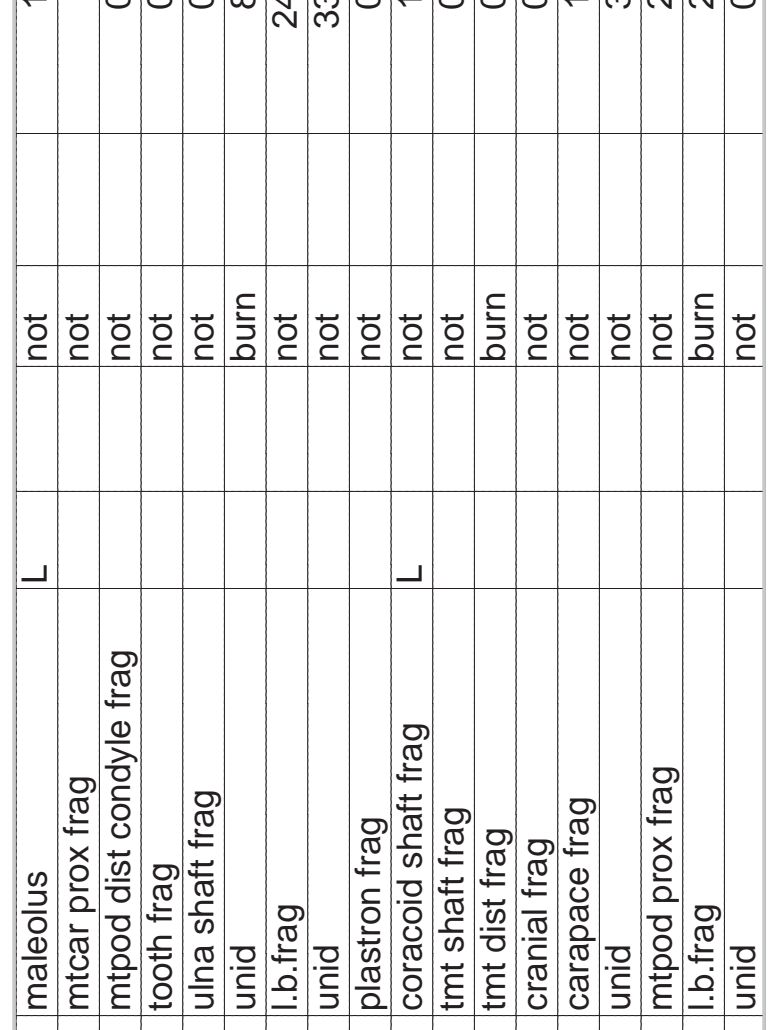

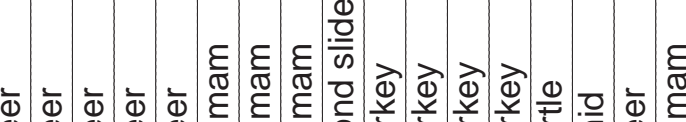

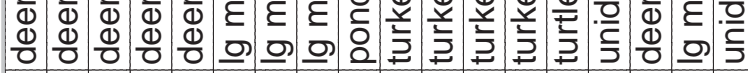

- - - -

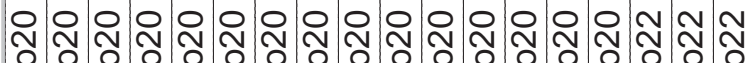

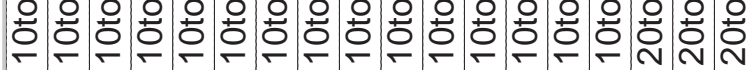

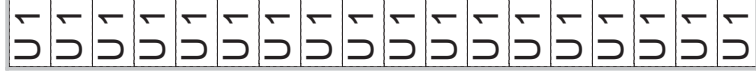





\section{APPENDIX 2, CHIPPED STONE TOOLS FROM THE AREA OF 41CE421 AND 41CE423}

\section{Mark Walters and Timothy K. Perttula}

In the surface collections on the Faulkinberry lands were a group of chipped stone tools found in the vicinity of 41CE421 and 41CE423. This appendix discusses each of these chipped stone tools individually. Measurements are in $\mathrm{mm}$.

\section{Arrow points}

Unidentified (UID) arrow point. Gray chert with white inclusions on stem and barb (Figure 19a). Unifacially worked; parallel to slightly expanding stem; rectangular barbs.

$\begin{array}{ll}\text { Length } & 37.9 \\ \text { Width } & 21.0 \\ \text { Thickness } & 3.4 \\ \text { Stem width } & 9.5\end{array}$

Perdiz arrow point (Figure 19b). Gray chert. Serrated blade, long contracting and pointed stem, and deep downward-pointing barbs; bifacially flaked.

$\begin{array}{ll}\text { Length } & 31.1 \text { [broken at tip] } \\ \text { Width } & 18.0 \text { [at barbs] } \\ \text { Thickness } & 3.0 \\ \text { Stem width } & 4.0\end{array}$

Perdiz arrow point (Figure 19c). Translucent gray Novaculite; serrated blade; stem missing; deep, downward-pointing barb; bifacially flaked.

$\begin{array}{ll}\text { Thickness } & 2.8 \\ \text { Stem width } & 3.6\end{array}$

Perdiz arrow point (Figure 19d). Light gray chert; contracting stem [broken]; short downward-pointing barbs; unifacially flaked.

$\begin{array}{ll}\text { Width } & 14.0 \\ \text { Thickness } & 2.9 \\ \text { Stem width } & 3.3\end{array}$

UID arrow point (Figure 19e). Light gray chert; very short contracting stem; rectangular shoulders; unifacially flaked.

$\begin{array}{ll}\text { Width } & 16.0 \\ \text { Width } & 11.0 \\ \text { Thickness } & 2.8 \\ \text { Stem width } & 1.3\end{array}$




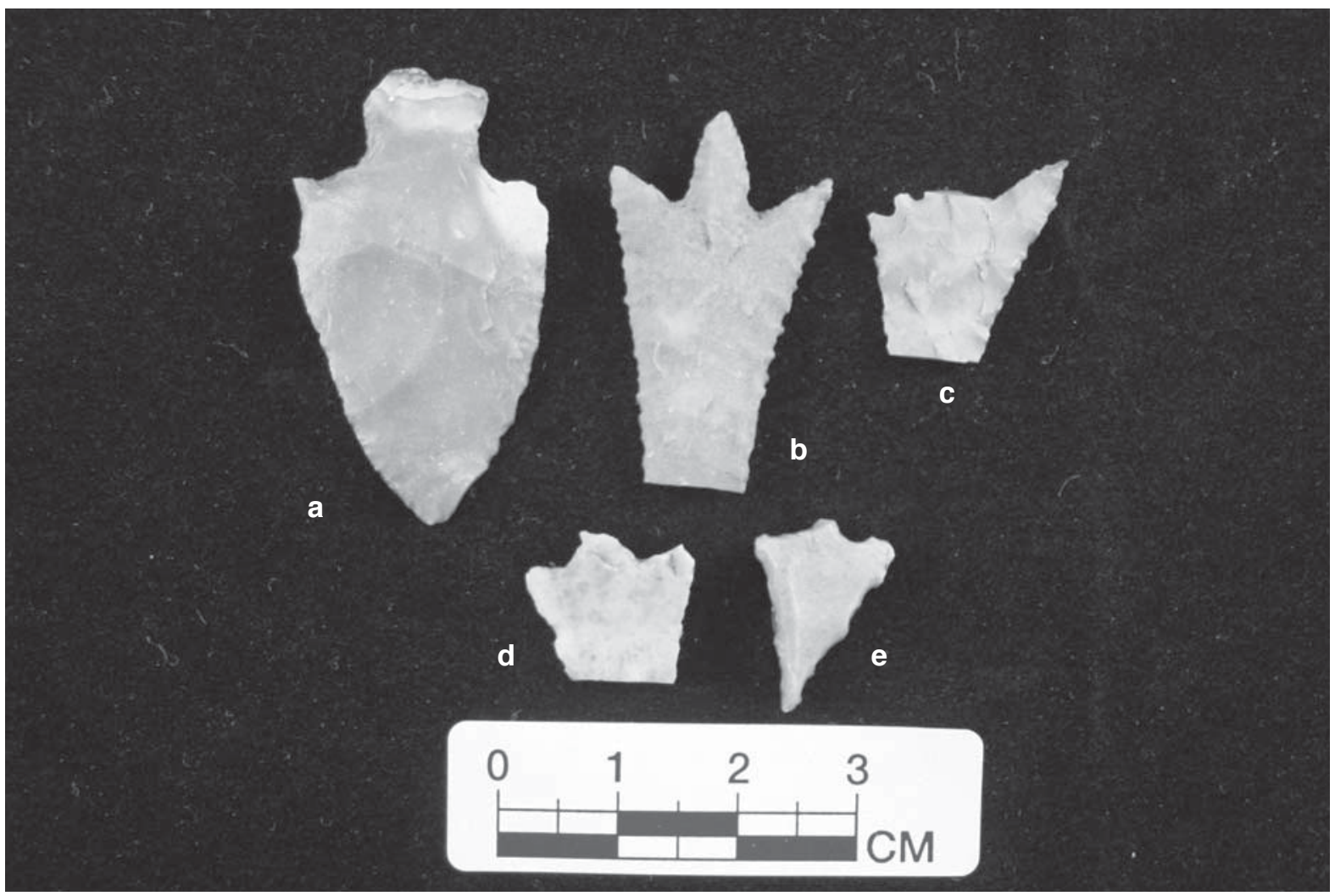

Figure 19. Arrow points: a, e, unidentified; b-d, Perdiz.

\section{Dart points}

Godley dart point (Figure 20a). Light gray chert; white and black inclusions; unifacially flaked; cortex on stem and blade; expanding stem and concave base.

$\begin{array}{ll}\text { Length } & 52.0 \\ \text { Width } & 17.5 \\ \text { Thickness } & 5.9 \\ \text { Stem width } & 12.7\end{array}$

Morrill dart point (Figure 20b). Dark gray chert with white inclusions; parallel stem and flat, snapped base; re-sharpened blade.

$\begin{array}{ll}\text { Length } & 43.0 \text { [tip broken] } \\ \text { Width } & 20.2 \\ \text { Thickness } & 9.2 \\ \text { Stem width } & 13.9\end{array}$

Yarbrough dart point (Figure 20c). Light gray chert; bifacially flaked; expanding stem; convex base; small downward-pointing barbs.

$\begin{array}{ll}\text { Length } & 45.2 \text { [tip missing] } \\ \text { Width } & 23.9 \\ \text { Thickness } & 9.2 \\ \text { Stem width } & 15.9\end{array}$


UID dart point (Figure 20d). Petrified wood; bifacial flaked; parallel stemmed; flat to slightly convex stem; small rectangular barbs; short stem relative to blade.

$\begin{array}{ll}\text { Length } & 37.5 \\ \text { Width } & 22.0 \\ \text { Thickness } & 8.0 \\ \text { Stem width } & 17.0\end{array}$

UID dart point (Figure 20e). Bluish-gray chert from a Central Texas lithic raw material source; bifacially flaked; re-sharpened blade.

$\begin{array}{ll}\text { Length } & 35.9 \\ \text { Width } & 21.5 \\ \text { Thickness } & 9.0 \\ \text { Stem width } & 15.1\end{array}$

Palmillas dart point (Figure 20f). Dark gray chert; re-sharpened blade; parallel to slightly expanding stem.

$\begin{array}{ll}\text { Length } & 33.0 \\ \text { Width } & 22.0 \\ \text { Thickness } & 7.5 \\ \text { Stem width } & 11.8\end{array}$

Gary dart point (Figure 20g). Yellow-gray chert; brown cortex on stem; unifacially flaked.

$\begin{array}{ll}\text { Length } & 35.0+\text { [tip missing] } \\ \text { Width } & 25.5 \\ \text { Thickness } & 7.9 \\ \text { Stem width } & 14.0\end{array}$

UID dart point (Figure 20h). Dark grayish-brown chert from a Ouachita Mountains source; expanding stem; flat to slightly convex base; small rectangular barbs; re-sharpened blade.

\section{Probable Middle Archaic dart points}

UID dart point (Figure 21a). Yellowish-gray chert; bifacially flaked; extensively re-sharpened blade.

$\begin{array}{ll}\text { Length } & 23.6 \\ \text { Width } & 18.9 \\ \text { Thickness } & 7.2 \\ \text { Stem width } & 15.1\end{array}$

Morrill dart point (Figure 21b). Heat-treated gray chert; cortex on base; parallel stem and flat base; resharpened blade.

$\begin{array}{ll}\text { Length } & 33.2 \\ \text { Width } & 16.0 \\ \text { Thickness } & 7.4 \\ \text { Stem width } & 13.8\end{array}$




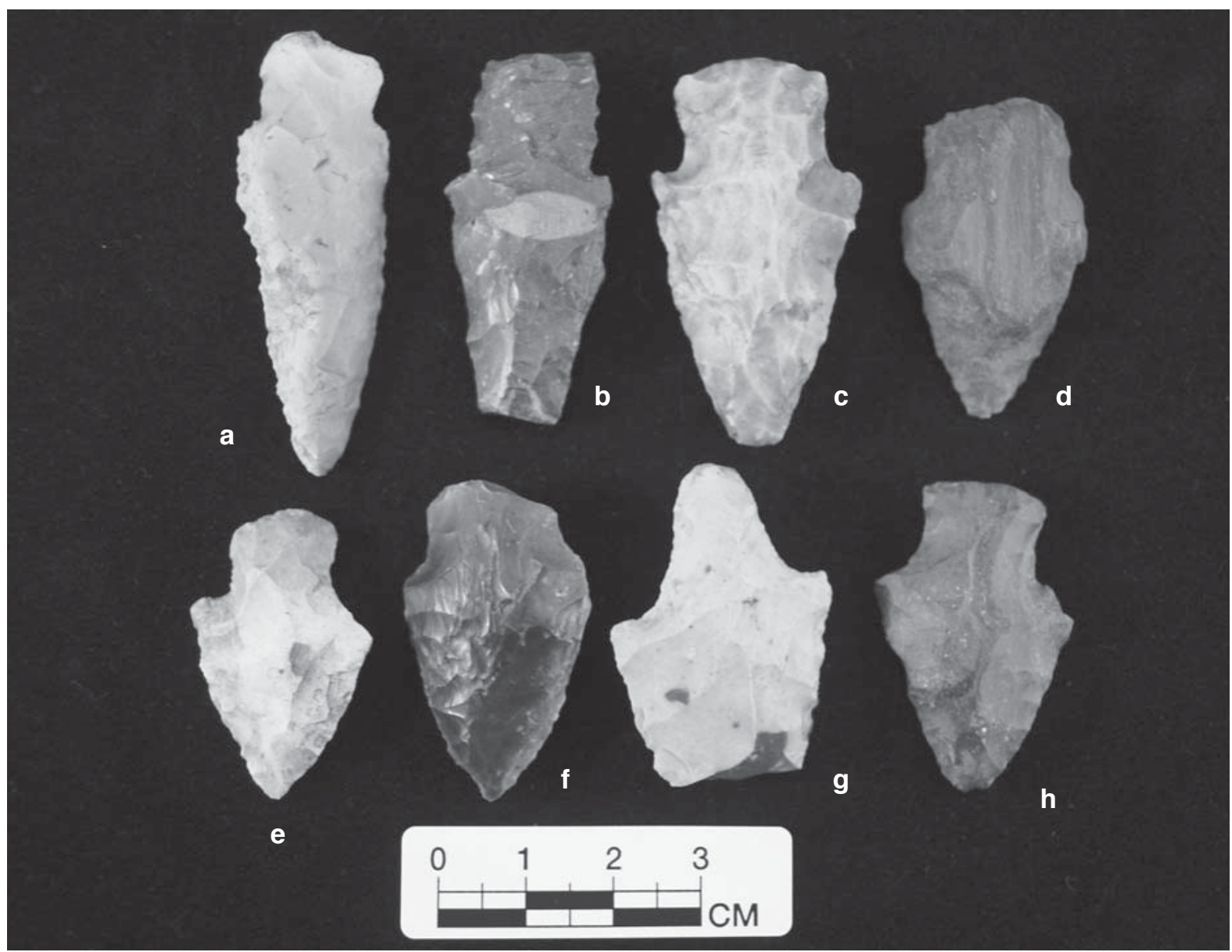

Figure 20. Dart Points: a, Godley; b, Morrill; c, Yarbrough; d-e, h, unidentified; f, Palmillas; g, Gary.

UID dart point (Figure 21c). Quartzite; bifacial flaked; re-sharpened blade; expanding stem with a shallow concave base (11.0 $\mathrm{mm}$ deep).

$\begin{array}{ll}\text { Length } & 28.0 \\ \text { Width } & 14.0 \\ \text { Thickness } & 7.8 \\ \text { Stem width } & 11.6\end{array}$

UID dart point stem fragment (Figure 21d). Dark gray chert; parallel and straight stemmed; bifacially flaked.

$\begin{array}{ll}\text { Thickness } & 6.7 \\ \text { Stem width } & 15.4\end{array}$

UID dart point (Figure 21e). Light gray chert; expanding stem with shallow concave base $(6.0 \mathrm{~mm})$; extensively re-sharpened blade; bifacially flaked. 


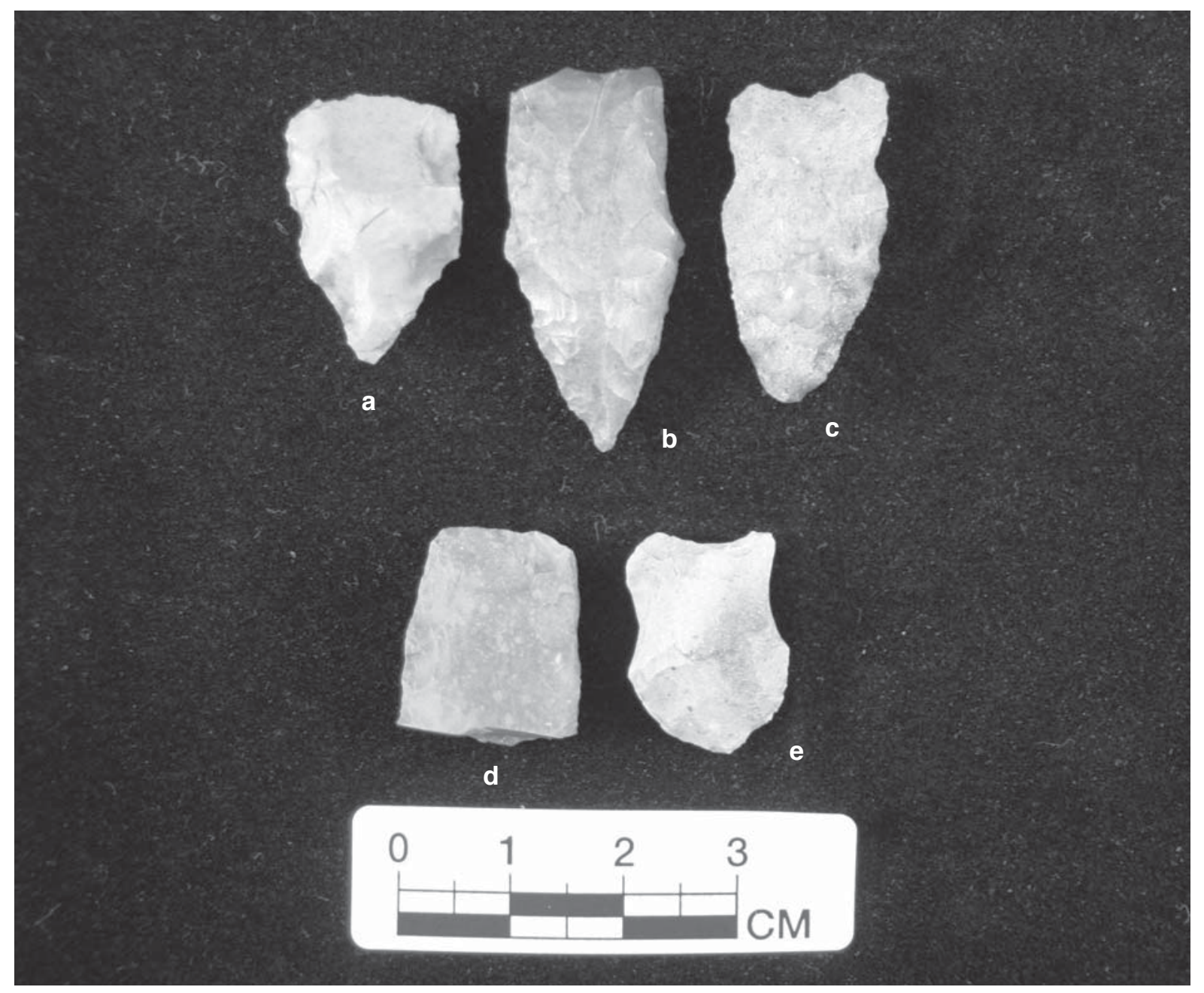

Figure 21. Probable Middle Archaic dart points: a, c-e, unidentified; b, Morrill.

\section{Late Paleoindian points}

Late Paleoindian point base, cf. Dalton/Plainview (Figure 22a). Light gray chert; bifacially flaked with edge grinding; concave base.

$\begin{array}{ll}\text { Length } & 29.2 \\ \text { Width } & 21.0 \\ \text { Thickness } & 7.6 \\ \text { Stem width } & 21.0 \text { [ear to ear] } \\ \text { Length of flute scars } 19.0,16.5, \text { and } 13.8 \\ \text { Length of grinding } 17.0,16.2,18.0,18.0\end{array}$

UID Lanceolate dart point (Figure 22b). Yellowish-gray chert; parallel stemmed; edge and stem grinding; bifacially flaked; flat base; reworked into drill.

$\begin{array}{ll}\text { Length } & 30.0 \text { [tip missing] } \\ \text { Width } & 17.7 \\ \text { Thickness } & 6.3 \\ \text { Stem width } & 16.5 \text { [near base] }\end{array}$


Angostura dart point (Figure 22c). Yellowish-gray chert; bifacial worked; flat base with hinged flake; edge grinding; reworked into drill.

$\begin{array}{ll}\text { Length } & 26.0 \text { [tip missing] } \\ \text { Width } & 14.0 \\ \text { Thickness } & 4.9 \\ \text { Edge grinding } & 12.5,15.0\end{array}$

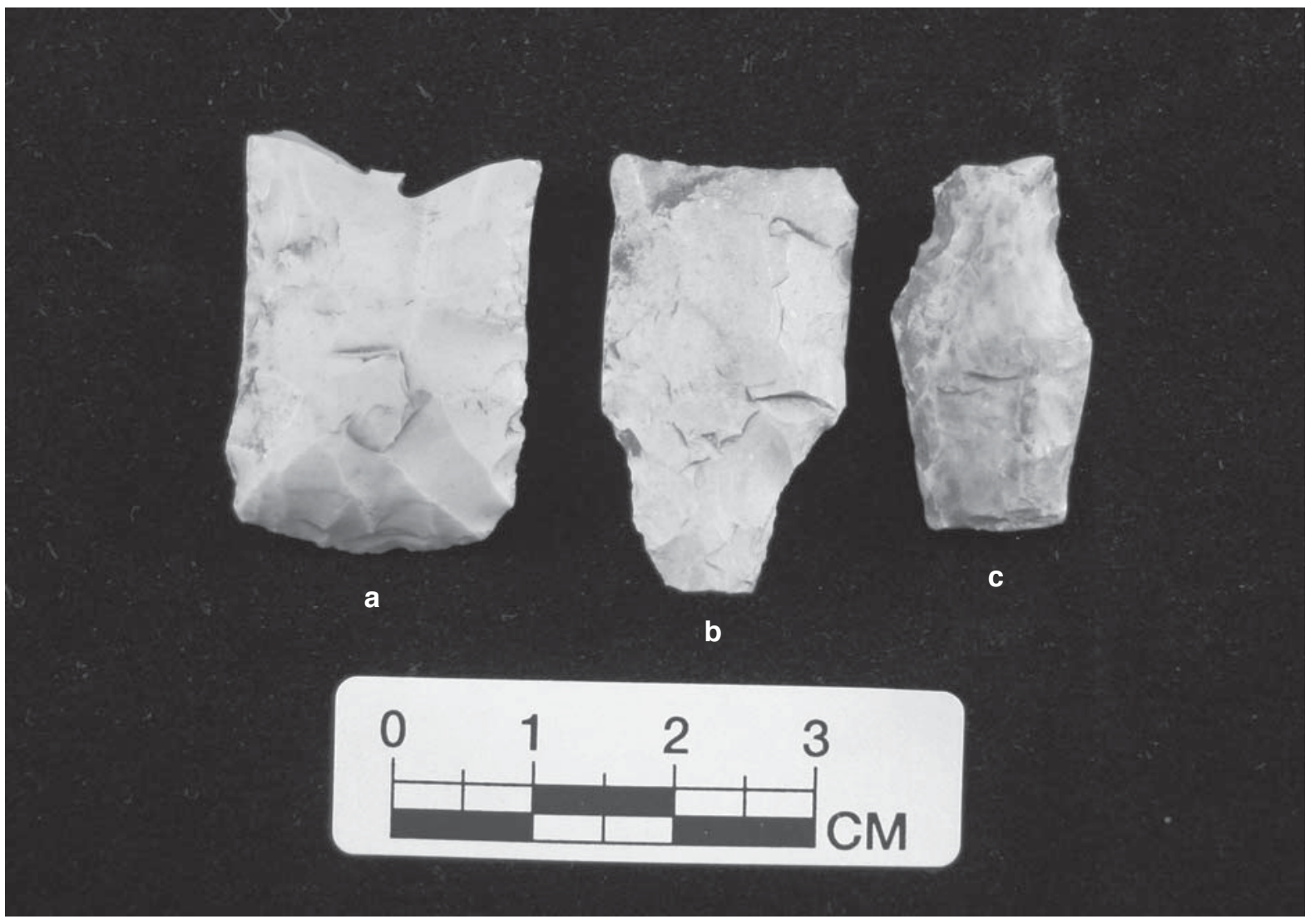

Figure 22. Late Paleoindian points: a, cf. Dalton/Plainview; b, unidentified lanceolate point; c, Angostura. 